\title{
MAKALELER
}

\section{Abdülhamid Döneminde Dinî Yayıncılık: İslâmî Metinleri Kim Üretir?-II}

\author{
Religious Publishing in Abdulhamid II Era: Who Produces the \\ Islamic Texts? -II
}

\section{Filiz DIĞIROĞLU*}

Öz: Osmanlı metin dünyasında hem ilmiyenin hem de halkın ihtiyacını karşılayacak dinî metinler her dönem var olmuştur. Matbaanın yaygınlaşması ve Tanzimat reformlarının etkisi ile çeşitlenen Osmanlı metin dünyasında da dinî metinler ağırlığını korumuştur. Bu makale, II. Abdülhamid döneminde üretilen İslâmi metinlerden ziyade onların üreticilerini tespit etmeyi amaçlamaktadır. Çünkü dönemin siyasi ve ilmi havası içerisinde dinî bilginin üretimini sağlayanların kimlikleri, metinlerin mahiyeti başta olmak üzere birçok şeye etki edebilir. Makale 'II. Abdülhamid döneminde dinî metinleri kim üretir?’ sorusuna cevap aramaktadır. Bu sorunun cevabı II. Abdülhamid döneminde kurumsal bir yapıya kavuşan ve etkili bir biçimde uygulanan matbuat denetim mekanizmasının faaliyetlerine bakılarak bulunabilir. Bu bağlamda faaliyetlerini denetimin en üst kurumu olan Maarif Nezareti’ne bağlı olarak sürdüren Encümen-i Teftiş ve Muayene Heyeti kayıtları incelendi. Söz konusu dinî metin olunca Maarif’teki heyete yardımcı olmak üzere Bab-ı Fetva'da kurulan Tetkik-i Müellefat Heyeti’nin defterleri taranarak çeşitli veri setleri oluşturuldu. Çünkü bu defterler, incelenen eserin adı, konusu, müellifi, telif türü, incelemeyi talep eden kişi/kurum ile eserin yayınlanıp yayınlanmayacağına dair görüşler gibi oldukça zengin bilgiler içermektedir. Dolayısıyla Bab-1 Fetva'daki defter kayıtları, söz konusu sorunun cevabı için en uygun zemini oluşturmaktadir.

Meşihat’taki Tetkik-i Müellefat Heyeti’nin muhatapları, ruhsat alma girişiminde bulunan diğer bir deyişle dinî eser neşretmek isteyen kişi ve kurumlardır. Bu heyetin kayıtlarına göre basım izni müracaatında bulunanlar müellif, mütercim, muhaşşi gibi doğrudan metin üretimine katkıda bulunanlar ile gerek medrese ders kitapları gerekse halka yönelik ilmihal kitaplarını basmak üzere ruhsat başvurusunda bulunan yayıncılardır. Metin üretimine doğrudan katkıda bulunanlar kimliklerine göre tasnif edildiğinde bürokrat, ulema, talebe, meşayih ve tarikat mensubu gibi çeşitli sosyal gruplar ile karşılaşılmış, ulema vasfını barındıranlar bu makaleye konu edilmiştir. Ruhsat başvurusunda bulunan müracaat sahipleri incelendiğinde ortaya çıkan en çarpıcı sonuç, Osmanlı ulemasının metin üretimindeki tekelini artık kaybettiğidir. Her ne kadar tekeli yitirse de Osmanlı uleması, dinî eser telif eden ikinci büyük sosyal grup olarak varlığını devam ettirmiştir. Elinizdeki çalışma müellif ulemanın kategorik tasniflerle kimlerden teşekkül ettiği, ne tür eserler kaleme aldığı ve bu eserlere karşı devletin tutumunu ortaya

* Dr. Öğr. Üyesi, Marmara Üniversitesi Fen-Edebiyat Fakültesi Bilgi Belge Yönetimi, filiz.digiroglu@marmara.edu.tr Orcid No: 0000-0001-9319-8340 
koymaktadır. Bu tasnifler sayesinde müellif ulemanın çeşitliliği ile Osmanlı coğrafyasındaki dağılımı ortaya çıkarılmaktadır.

Tetkik-i Müellefat Heyeti kayıtları, II. Abdülhamid döneminde matbu dinî neşriyatın seyrini, ruhsat başvurusunda bulunan eserlerin incelenme sürecini, heyet üyelerinin verdiği kararları göstermektedir. İște bu makale bir dinî eserin yayınlanıp yayınlanmayacağına dair kararları ve özellikle ruhsat alması uygun görülmeyen eserlerin 'sakıncalı' bulunan taraflarını kaynakların müsaade ettiği nispette tespit etmiştir. Aslında bu tespitler devletin dinî neşriyata müdahelesinin boyutlarını ortaya koyabilecek ufuk açıcı bilgilerdir. Bu makale müellif ulemanın eserlerine ruhsat alma girişimine odaklanarak ulemanın ulemayı tedkik ettiği süreci anlamaya çalışmaktadır. Bu bağlamda Osmanlı ilmiyesinin üst düzey ulemasından müteşekkil heyetin denetim ve kontrol yetkisini nasıl kullandığı gözlenmiştir. Devletin incelemelerde bulunan heyet başkanından taşra medreselerinde tahsil-i uluma devam eden talebeye kadar herkese eşit mesafede bir tutum sergilediği müşahede edilmiştir. Aynı şekilde denetim mekanizmalarının faili olan ulemanın, müellif/denetlenen ya da heyet üyesi/denetleyici sıfatlarını haiz olarak mekanizma ile farklı düzeylerde ilişkiler kurduğunda da sistemin adilane suretle işletildiği görülmüştür. Bunların yanı sıra söz konusu dönemde taltif edilen müellif ulema ile dinî metin türleri ve telif meselesine dair bazı ayrıntılar da ele alınmıştır.

Anahtar Kelimeler: II. Abdülhamid, Meşihat, ulema, Çerkeşşeyhizade Mehmet Tevfik Efendi, matbuat denetimi.

Abstract: Among Ottoman texts, there have always been religious texts that responded to the needs of both the scholars and the common people. These religious texts were upheld to be the focusing point, even after the Ottoman texts increased in variety due to the printing press becoming widespread and the influence of the Tanzimat reforms. Thus, this paper mainly aims to identify the producers of religious texts rather than to study the texts in the era of Abdulhamid II. This is because, under the political and scientific atmosphere of the era, identities of those who produced the religious knowledge had an effect on a variety of things, among them especially the character of the texts. This paper's main pursuit is to search for the answer to the question as to who were responsible for producing the religious texts in the era of Abdulhamid II. The answer can be found by looking into the activities of the printing press control mechanism that was obtained at an institutionalized structural level and was effectively applied in that era. In this context, the records of Encümen-i Teftiş ve Muayene Heyeti (the Office of Sheikh al-Islam), that was working dependently with the Ministry of Education, the supreme authority of printing press control mechanism, have been examined.

As these religious texts are researched and examined, diverse data sets are composed by searching the registers of Tetkik-i Müellefat Heyeti (the Council of Examination of Written Works) that were found within the Bab-1 Fetva (the Office of Sheykhu'l-Islam). These registers comprise of very rich data like title of the book under examination, its author, topic and genre, the person or agency that requested the examination and the evaluation and decision of the council about whether it will be published or not. Thus the registers in Bab-1 Fetva (the Office of Sheikh al-Islam) are the most suitable sources for this research. Moreover, the interlocutors of the council in the office of Sheikh al-Islam, were the persons responsible to demand the permit for publishing, in other words, they were the persons or agencies who required the publication of a religious text. According to the registers of the council, the interlocutors were authors, translators or annotators who contributed directly to the production of text and to the publishers who requested the permit for publishing the academic textbooks and the religious instruction for public readers. As classifying the identities of the direct contributors to the 
production of texts, it appears that they belong to the various social groups like bureaucrats, scholars, disciples, sheikhs and members of religious orders. From among them, only the scholars will be discussed further in this paper. The most impressive result of examining those who requested the permit for publishing is that of Ottoman scholars had lost their monopoly in the production of the texts. Nevertheless, they continued to be the second largest group in the production of religious texts.

This paper presents the categorization of the scholar-authors according to their identities, the variety of the texts they produced and the attitude of the state in the face of these texts. Due to these categorizations, it offers the research the variety of the scholars-authors and their diffusion in Ottoman lands. The registers of Tetkik-i Müellefat Heyeti (the Council of Examination of Written Works), demonstrate the progress of religious publication in the era of Sultan Abdulhamid II, the examination process of the books issued to the authorization and the decisions of the members of the council. This paper determines the evaluations on the religious texts to be published or not, and especially the "objectionable aspects" of the texts of which publication was rejected. In fact, these determinations give stimulating data that can reveal the dimensions of the state's intervention in religious publication. By focusing on scholar-authors who applied for permission, this paper attempts to demonstrate the process in which scholars investigated other scholars. In this context, it shows how the council, consisting of high-ranking ottoman scholars, used their authority of supervision and control. It has been observed that the state stands in an equal distance to every request from the head of council to the disciple from a provincial madrasa. Likewise, it can be observed that being actors of the control mechanism, the scholars fairly ran the system even when they were involved in different kinds of relationships with the mechanism as the members of the council to the investigators. In addition to these diverse aspects of control mechanism, this paper deals with some further details about published scholar-authors, genres and the process of compiling the religious texts.

Keywords: Abdulhamid II, the Office of Sheikh al-Islam, Scholar, Control of Printing Press, Tcherkesh-sheikhi-zadeh Mehmed Tewfik Efendi

\section{Giriş}

Matbaanın yaygınlaşması ve Tanzimat reformlarının uygulanmasının ardından "yeni okur" tipi için yeni kitap türleri piyasada yer almaya başlamıştır. Fakat yeni metin türleri devreye girse de Osmanlı metin dünyasında dinî metinler ağıllığını her zaman korumuştur. Dinî bilginin üretimini doğrudan veya dolaylı olarak sağlayan müellif, mütercim ve yayıncıların kimliklerine odaklanacak bu çalışma, "II. Abdülhamid döneminde dinî metinleri kim üretir?” sorusunun izini süren makale serisinin ikincisini oluşturmaktadır. ${ }^{1} \mathrm{Bu}$ sorunun cevabının aranacağı en makul zeminlerden biri, II. Abdülhamid dönemindeki matbuat denetim mekanizmaları ile bunlara muhatap olan dinî metin üreticisi müellif ve yayıncıların ruhsat başvuru süreçleridir. Kitap yayınlama süreçlerinin başlangıcını oluşturan ruhsat baş-

1 Filiz Dığıroğlu, “II. Abdülhamid Döneminde Dinî Yayıncılık: İslami Metinleri Kim Üretir? - I”, History Studies, Mart 2017, IX, sy. 1, s. 85-110. 
vurusu, II. Abdülhamid dönemindeki matbaa açma, kitap toplatma, kitap/gazete yasaklama gibi birçok basamaktan oluşan karmaşık matbuat denetim sisteminin bir parçasıdır.

Matbuat denetimi II. Abdülhamid ile başlamasa da onun döneminde güçlü bir kurumsal yapıya kavuşmuş ve oldukça organize bir şekilde işletilmiştir. Bu dönemde dinî metin olsun ya da olmasin metin neşretmek isteyenler, Maarif Nezareti bünyesindeki Encümen-i Teftiş ve Muayene Heyeti’nden izin almak zorundaydı. Ruhsat/basım izni alma işlemi, matbuat denetim mekanizmasının en üstündeki bu kurumun işlerinden sadece biriydi. Basım izni alınmak istenen dinî bir metin ise Maarif Nezareti’nin zikredilen birimi, söz konusu eser hakkında Meşihat'tan görüş isterdi. Çünkü Meşihat'ta dinî kitapları değerlendiren Tedkik-i Müellefat Heyeti adında müstakil bir heyet kurulmuştu. Bu heyet daha sonraları Meşihat'ta Mushafları denetlemekle görevli heyetle birleştirilerek Tedkîk-i Mesâhif ve Müellefât-1 Şeriyye ismiyle görevine devam edecektir. ${ }^{2}$

II. Abdülhamid döneminde dinî yayınları kontrol etmek amacıyla kurulan Tedkik-i Müellefat Heyeti’nin gündemindeki kitaplar/risâleler, "II. Abdülhamid döneminde dinî metinleri kim üretir?” sorusu çerçevesinde değerlendirildiğinde ilginç sonuçlarla karş1laşılmıştır. Bu sonuçlara geçmeden önce Tetkik-i Müellefat Heyeti defterlerindeki kayıtların içeriğine temas edilmelidir. Heyetin karar defterleri incelenen eserin adı, konusu, müellifi, telif türü, incelemeyi talep eden kişi/kuruma dair bilgiler ile eserin yayınlanıp yayınlanmayacağına dair görüşler içerir. Ancak her bir kayıt yukarıda sıralanan bilgilere eşit derecede yer vermez. Yani bu kayitlardaki bilgiler sistematik değildir. ${ }^{3}$ Tüm s1nırlılıklarına rağmen defterlerdeki verilerin tamamı ele alınmış ve bu makalenin ilk başlığında değerlendirilmiştir. Bu değerlendirmelerin başında, II. Abdülhamid döneminde dinî metin neşretmek isteyenlerin büyük çoğunluğunu, Osmanlı Devleti’nin bürokrat ve memurlarının oluşturması gelir. Ulema sınıfı II. Abdülhamid döneminde İslâmî metinleri üretmedeki tekelini kaybettiyse $\mathrm{de}^{4}$ bu alanda faaliyet gösteren ikinci büyük meslek grubu olarak varlığını devam ettirecektir. İşte bu makale dinî metin üretim ve denetim sürecinde ulemanın rolünü siyasî, bürokratik ve sosyal konumlarına odaklanarak ele alacaktır. Ayrıca II. Abdülhamid dönemi Osmanlı ulemasının ne tür kitaplar telif ettiği ile denetim mekanizmalarındaki ilmiye ricalinin bu kitapları ve müellifleri nasıl ted kik ettiği ortaya konacak, incelemelerde ne tür değişiklikler talep edildiği, kaynakların elverdiği ölçüde tespit edilecek, II. Abdülhamid dönemi merkez ve taşra ulemasının kitap/risâle yayınlama ruhsat başvuruları üzerinden bu döneme dair İslâmî neşriyatın/telifatın bütüncül bir tablosu ortaya konmaya çalışılacaktır.

2 Bu meclis hakkında ayrıntılı bilgi için bk. Filiz Dığıroğlu, "II. Abdülhamid Dönemi Matbuat Politikaları: Mushaf Basımı ve Dini Neşriyat”, II. Abdülhamid Han ve Dönemi (ed. Fahrettin Gün - Halil İbrahim Erbay), Ankara: TBMM Basımevi, 2017, s. 634-7.

3 Bu defterler ve kaynaklık değeri hakkında ayrıntılı bilgi için bk. Filiz Dığıroğlu, "Osmanlı Matbuat Tarihinin Kaynağı Olarak Meşihat Arşivi”, II. Uluslararası Osmanlı Coğrafyası Arşiv Kongresi (20-24 Kasım 2017), (basılmamış tebliğ). 


\section{II. Abdülhamid Döneminde Dinî Neşriyatın Aktörlerine Dair}

Tetkik-i Müellefat Heyeti’nin verileri II. Abdülhamid döneminde dinî neşriyat faaliyetinde bulunanları tahlil etmeye imkân verecek detaylara sahiptir ve bundan dolayı çeşitli grafiklerde ele alınacaktır. Öncelikle bir dinî eser için ruhsat almaya girişenler veya bir dinî eser hakkında inceleme talep eden kurumlar belirlenerek "başvuru türlerine" göre grafiğe yansitılacaktır. ${ }^{5} \mathrm{Bu}$ grafikte kitap yayınlama ya da denetleme başvurusu yapanlar "bireysel", "kurumsal" ve "piyasa" başlıkları altında ele alınmıştır. "Bireysel" başlığı büyük çoğunluğunu bizzat müelliflerin oluşturduğu şahsî ruhsat başvurularını içermektedir. "Kurumsal” başlığı Zaptiye Nezareti ve Rüsumat Emaneti başta olmak üzere Posta ve Telgraf Nezareti gibi devletin diğer kitap denetim mekanizmalarından gelen müracaatlar ile Mabeyn Başkitabeti taleplerini kapsar. "Piyasa" başlı̆̆ı ise matbaacı, sahaf ve kitapçılardan müteşekkil başvurulardan oluşmaktadır. ${ }^{6}$

Grafik 1. Başvuru Türleri (1889-1906)

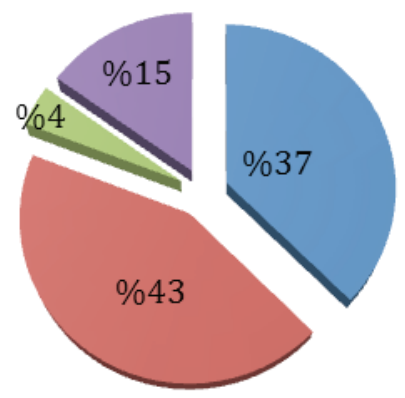

Belli değil

Bireysel

Kurumsal

Piyasa

Kaynak: Meşihat Arşivi, Defter nr. 1509, 1784, 1785.

Müracaatların \%43 bireysel, \%37 belirsiz, \%15 piyasa ve \%4 kurumsal şeklinde dağılım gösterdiği grafikte bireysel başvuruların çoğunlukta olduğu açıkça görülür. Bu durum XIX. ve XX. yüzyıl Osmanlı dünyasında üretilen metinlerin yazarları tarafından bastırma ve yayınlatma eğiliminin hâkim olmasından kaynaklanır. Ruhsat başvurularında müracaat sahibinin kimlik bilgilerinin yeterli olmaması nedeniyle belirlenemeyenlerden oluşan "Belli değil” başlı̆̆ı, ikinci büyük dilim olarak grafikte yer almaktadır. Elbette müelliften farklı bir tonda metin üretimine katkı sağlayan piyasa (matbaacı, yayıncı) ise müracaat yoğunluğu itibariyle üçüncü sıradadır.

5 Heyete gelen müracaatlar, başvuru sahibinin kendini tanımlama biçimine göre ele alınmıştır. Ayrıca heyet önüne mükerrer surette gelen eserler de tek müracaat olarak grafikte yerini almıştır.

6 Bu makelde kullanılan grafikler yazarın şu makalesinden elde edilmiştir (bk. Dığıroğlu, "II. Abdülhamid Döneminde Dinî Yayıncılık", s. 91-5). 
Grafik 2. Başvuru sahiplerinin mesleki dağılımı (1889-1906)

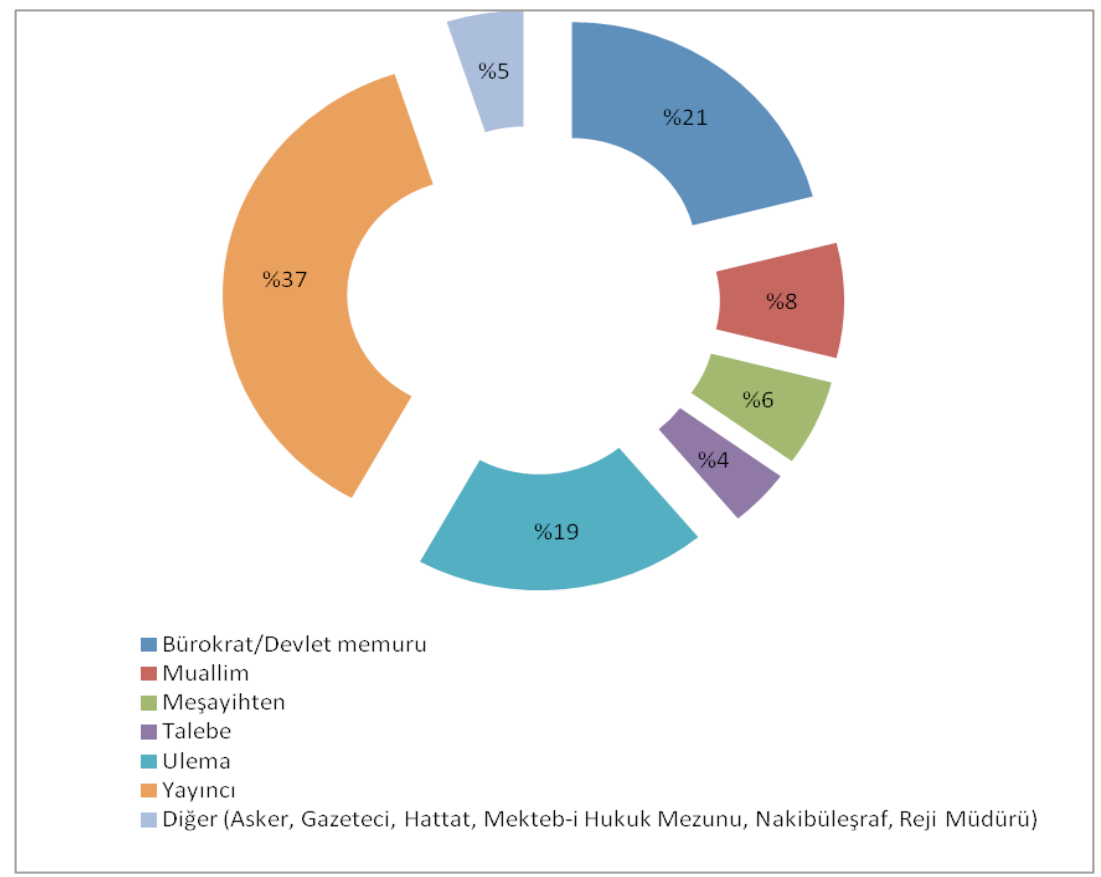

Kaynak: Meşihat Arşivi, Defter nr. 1509, 1784, 1785.

Başvuru sahiplerinin mesleki dağılımlarını gösteren yukarıdaki grafik, 'dinî metinleri kimin ürettiğì sorusunu büyük oranda cevaplayacaktır. Burada metin üretiminin en geniş anlamıyla hem metinleri telif eden hem de neşredenleri kapsadığ belirtilmelidir. Grafikte yayıncılar ağırlıklı görünse de onlar metin üretimine sadece neşriyat noktasında katkı yapmış ve medrese talebelerine yönelik olarak klasik metinlerin ya da halka yönelik olarak modern dönemde ortaya çıkan muhtasar türlerin tedavüle girmesini sağlamışlardır. \%21'lik payı ile bürokrat ve \%19'luk payı ile ulema kategorisinin ise esas metin üretenler olduğu hatırdan çıkarılmamalıdır. Metin üretimine katkıları bağlamında $\% 8^{\prime}$ lik payı ile muallimler, $\% 6$ 'lık payı ile tarikat ehli ve \%4'lük payı ile talebeler göze çarpmaktadırlar. \%8'lik dilimde yer alan muallimlerin bürokrat-devlet memuru kategorisine dâhil edilmesi durumunda bu kategorinin dilimi yaklaşık \%30 bandına ulaşacaktır. Burada akla "Bürokrat-devlet memuru kategorisindeki gözle görünür artışın sebebi nedir? Ulema dinî metin üretiminde yegâne adres iken ne oldu da II. Abdülhamid döneminde bürokrat ve devlet memurları dinî metinler yazmaya başladılar?" soruları gelmektedir. Bu soruların cevaplarının bir kısmının, Osmanlı modernleşmesi ve II. Abdülhamid dönemi politikaları ile doğrudan veya dolaylı alakalı olduğunu ve ilk makalemizde kısmen ele alındığını zikretmekle yetineceğiz. Burada ise ulemanın dinî eser telif etme durumu ve ruhsat alma süreçleri ele alınacaktır. 
Grafik 3. Başvuru sahiplerinin mesleki çeşitliliği (1889-1906)

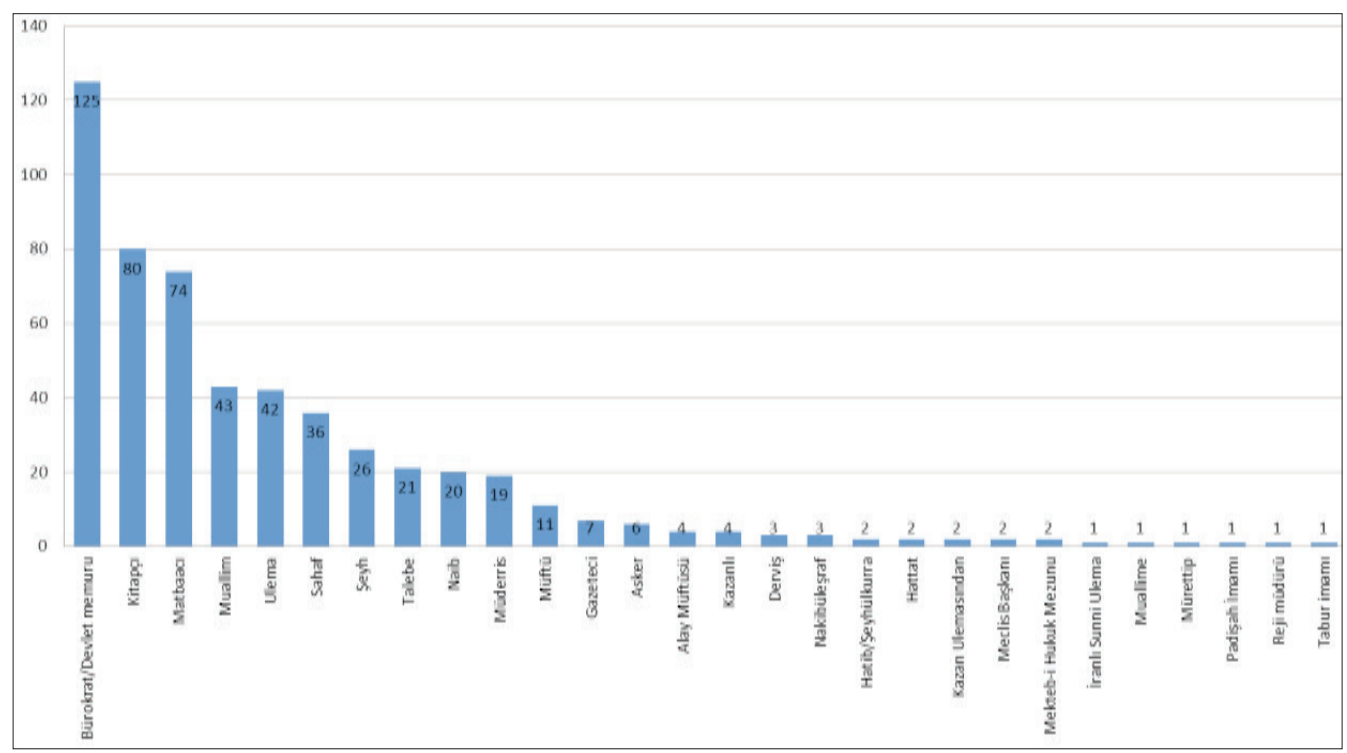

Kaynak: Meşihat Arşivi, Defter nr. 1509, 1784, 1785.

Dinî eser telif edenlerin mesleki çeşitliliğine bakmak, ulemanın dinî eser üretimindeki yerini tespit etmek bakımından faydalı olacaktır. ${ }^{7}$ Meslek türlerinin görüldüğü grafikte en yüksek oran yine bürokrat-devlet memuru kategorisidir. Bu grafikte bir önceki meslekî dağılım grafiğinin ötesine geçip, mesleklerin alt grupları gösterilmeye gayret edildi. Bürokrat-devlet memuru kategorisi en alt düzeydeki kâtipten valiye, muallimden müdüre, muhasebe memurundan paşaya kadar oldukça geniş bir memur kadrosunu bünyesinde barındırmaktadır. Yayıncı kategorisinin kitapçı, matbaacı, sahaf ve mürettipten teşekkül ettiği görülmektedir. Ulema kategorisinin içine dercedilen meslekler ise müderris, müftü, hatib, şeyhülkurra, naib, tabur imamı, padişah imamı, alay müftüsü ve iki müracaatı ile kayıtlara geçen Tedkik-i Müellefat Heyeti başkanıdır. ${ }^{8}$ Bir önceki mesleki dağılım grafiğinde \%6’lık payı ile eser telif edenler arasında bulunan tarikat ehli de müstakil olarak anılmalıdır. Eser telif edip basım onayı için müracaat eden şeyh efendi ve dervişan, ulema ve bürokratlardan ayrı bir kategoride değerlendirilmiştir. Müracaat sahiplerinin meslekî dağılımlarına dair ayrıntıların ardından "ulema” kategorisindeki başvurular ve heyetin bu başvuruları nasıl değerlendirdiği daha yakından incelenmelidir.

7 Başvuranların hangi meslek gruplarına mensup olduklarını biraz daha müşahhas hale getiren grafikte esas alınan, başvuru sahiplerinin kendilerini tanımlama biçimleridir. Dilekçelerinin sonunda yer alan kendilerini tanımlama biçimine göre düzenlenen bu grafikte, kimlik/meslek tanımlamalarının belirtilmediği müracaatlar gösterilememiştir. Ayrıca "Mekteb-i Hukuk mezunu" ya da "Kazanlı" gibi meslek kategorisinde sayılması meşkûk olan başvurular, kendilerini tanımladıkları biçimde grafiğe dâhil edilmiştir.

8 Ulema kategorisindeki bu mesleki çeşitlilik ilmiye hiyerarşisinin her basamağındaki âlimin eser telif ederek kariyerini taçlandırma isteğinin doğal bir sonucu olmalıdır. 


\section{Ulemanın Ulemayı Tedkiki: Tashih, Tadil ve Red}

\subsection{Merkez Başvuruları}

İslâm tarihi boyunca dinî bilginin üreticisi ve yorumlayıcısı olan âlimler kadar olmasa da dinî ilimlere dair eser telif eden bürokratlara da rastlanmaktadır. Bu bağlamda Osmanlı dönemi meşhur bürokratlarından Lütfi Paşa’nın dinî eser telifleri hatırlanabilir. ${ }^{9}$ Ancak bu durum hiç bir zaman nicelik olarak âlimlerin önüne geçecek boyutlara ulaşmamıştır. XIX. yüzyılın son çeyreğinde ise Osmanlı bürokrat ve memur kadrolarının dinî eser "telif performansı", ulemanınki ile yarışacak, hatta bazı zamanlar ulemanın önüne geçecek boyuta erişmişti. Bu durum Osmanlı modernleşmesi ile yakından alakalıdır.

II. Abdülhamid devrinde kitap telif edip bastırmak isteyen herkes devletten gerekli izni almak zorundaydı ve bu konuda kimseye bir iltimas tanınması söz konusu değildi. Dolayısıyla dinî metin üreten ister bürokrat ister ulema olsun Bab-1 Fetva'daki heyetin tedkikinden geçmektedir. Bu bağlamda payitahttaki müellif ulemanın Tedkik-i Müellefat Heyeti ile münasebeti ele alınmaya değerdir. Söz konusu münasebet, ilmiye hiyerarşisinin üst basamaklarındaki âlimlerden müteşekkil Tedkik-i Müellefat Heyetỉnin Osmanlı ulemasının eserlerini incelemesi ve onaylaması/reddetmesi sürecini kapsamaktadır. Bu süreç, heyetin eserleri değerlendirme esaslarından ziyade II. Abdülhamid döneminde merkez-taşradaki müellif ulemanın "telif performansı"nı anlamak için irdelenecektir.

İslâm âleminin birçok yerinde olduğu gibi Dersaadet'te de ulema, medreselerde ders okutmak, talebe yetiştirmek, icazet vermek, eser telif etmek suretiyle hizmetlerini sürdürmekteydi. Tedris, iftâ ve yargı hizmetini bünyesinde birleştiren ilmiyenin bu özelliği, Osmanlı Devleti'nin kuruluşundan beri mevcuttur. Tanzimat sonrası Osmanlida tedris ve yargı hizmetini modern kurumlarla paylaşmak zorunda kalsa da ulema, bürokrasinin dinî kanadını oluşturan Meşihat birimlerinde ya da Maarif, Adliye ve Evkaf Nezaretleri başta olmak üzere bürokrasinin diğer enstrümanlarında görevlendirilmeye devam etti. II. Abdülhamid döneminde ulemanın Maarif Nezareti’nde görevlendirilmesinin hususi birtakım sebepleri ve neticeleri olsa da, ${ }^{10}$ konumuz açısından Maarif Nezareti’ni özel kılan husus, dinî bürokrasi d1şında görev alan müellif ulemanın yoğunlaştı̆̆ı sahalardan biri olmasıdır.

9 Asafnamesi ve müverrihliği ile tanınan 16. yy. önemli devlet adamlarından Lütfi Paşảnın yirmi yıllık emeklilik döneminde hatırı sayılır miktarda dinî eser ürettiği görülmektedir. Lütfi Paşảnın İslâmi eser telifatını ve bu eserlerin kaynaklarını değerlendirerek Paşa’nın biyografisinde az bilinen bir yönünü ortaya çıkaran son dönemde yapılmış vasıflı bir çalışma için bk. Asım Cüneyd Köksal, "Bir İslâm Âlimi Olarak Lütfi Paşa", Osmanlı Araştırmaları, 2017, sy. 50, s. 29-72.

10 İlmiye mensuplarının maarif/mektep sisteminde istihdamı ve mektep programlarını düzenleyen komisyonda görev alması ile ilgili vurgu için bk. Mahmut Dilbaz, II. Abdülhamid Döneminde Mektep Sisteminde İslâm Anlayışı (doktora tezi, 2017), Ankara Üniversitesi Sosyal Bilimler Enstitüsü, s. 51, 118. Müfredat komisyonlarındaki ilmiye istihdamı hakkında ayrıca bk. Benjamin Fortna, Geç Osmanlı ve Erken Cumhuriyet Dönemlerinde Okumayı Öğrenmek (trc. Mehmet Beşikçi), İstanbul: Koç Üniversitesi, 2013, s. 121-2. 
Müellif ulemanın yapısını anlamak için genel itibariyle kariyerlerine, özelde ise kariyerlerinin hangi basamağında Bab-1 Fetva'daki heyetle muhatap olduğuna bakılmıştır. Bu usûl ile müellif ulemanın kimlerden oluştuğu müşahhas hale getirilecektir. İlk olarak Osmanlı bürokrasisinde görev yapan ulemanın eser telif edenleri "ulema-bürokrat" olarak tasnif edilmiştir. ${ }^{11} \mathrm{Bu}$ tasnif dâhilinde ulema-bürokratta aranan başlica özellik ise medrese icazetinden ziyade kariyerinde klasik ilmiye vazifelerinden birini icra etmesidir. ${ }^{12} \mathrm{Bu}$ tanımın daha iyi anlaşılması için Manastırlı İsmail Hakkı örnek olarak ele alınabilir. Telhîsu'l-kelâm fî berâhini akâidi'l-islâm'ın müellifi ${ }^{13}$ olarak kayıtlara yansıyan Manastırlı, Ayasofya Camii kürsü şeyhliğinden Fatih Camii müderrisliğine, Mekteb-i Hukuk'ta fikıhtan Darülfünun'da usûl-1 fıkıh ve tefsir müderrisliğine kadar geniş bir zeminde ilmi vazifelerini icra etmiş bir müderris ve âlimdir. Görüldüğü üzere Manastırlı, hem klasik ilmiye görevlerini ifa etmiş hem de dönemin en önemli yüksek eğitim kurumlarında birçok dinî derse girmiştir ${ }^{14}$ ve dolayısıyla bu makalede oluşturulan ulema-bürokrat kategorisine oldukça uygun bir isimdir. Ancak ilmiye kökenli olmakla beraber ilmiyeden vazife almamış ya da ilmiyede tahsil hayatına başlayan ancak başka sahalarda devam ederek Osmanlı bürokrasisinin farklı kademelerinde görev yapmış müellifler ise bu kategorinin dışında bırakılmıştır. ${ }^{15}$ Bunlar dinî eser telif eden bürokrat/memur kategorisinde değerlendirilerek bu makale serisinin ilkinde ele alınmıştır. ${ }^{16}$ Heyet defterindeki tanımlamaların esas alındığı tasniflerde müracaat sahipleri kendilerini bürokrasideki göreviyle tavsif ettiyse ve hakkında ilmiyede aktif görevi ile ilgili herhangi bir başka bilgi yoksa da bürokrat olarak değerlendirilmiştir.

11 Bu tasnif, Tetkik-i Müellefat Heyeti kayıtlarının "İslâmi metinleri kim üretir” sorusu çerçevesinde değerlendirilmesiyle oluşturulmuş ve müellif ulemanın alt kategorilerinden biri olarak zikredilmiştir. Ulema tasnifinde amaç sabit ayırım çizgileri çizmek değil, dinî metin üreten müellif ulemanın çeşitliliğine dair geniş örüntüleri ortaya koymaktır. Bu kategoriler, çeşitli metinlerin müelliflerini anlamak ve onlara dayanak oluşturan tavırları anlamlandırabilmek için ilmiye kariyerindeki yerlerini netleştirmek olarak görülmelidir.

12 Tasnifin daha iyi anlaşılması için Mehmed Zihni Efendi ve Mahmud Esad Seydişehrî örnekleri verilecektir: Medrese icazeti bulunmasına rağmen ilmiye payelerini ve görevlerini almamış olması, uzun yıllar hem mekteplerde muallimlik yapması hem maarif/matbuât kurumlarında üyelik ve başkanlık yapması ile klasik ilmiye müelliflerinin dışında bir profil sergileyen Mehmed Zihni Efendi bürokrat/memur kategorisinde değerlendirilmiştir (Zihni Efendi'nin benzer yönleri ile ele alındığı bir çalışma için bk. Dilbaz, II. Abdülhamid Döneminde Mektep, s. 79-81). Bu bağlamda medrese icazetinden sonra, Fatih dersiamlığı yapmış hatta Anadolu kazaskerliği payesine kadar yükselmiş ancak herhangi bir ilmiye görevini fiilen sürdürmemiş kalemiye mensubu olarak Mahmud Esad Seydişehrî de oldukça ilginç bir örnektir. Bu makalede Seydişehirli de bürokrat/memur kategorisinde değerlendirilmiştir (Seydişehirli biyografisi için bk. Kamil Yaşaroğlu, "Mahmud Esad Seydişehrî", Yaşamları ve Yapıtlarıyla Osmanlılar Ansiklopedisi, İstanbul: Yapı Kredi Kültür Sanat Yayıncılık, 1999, II, s. 68-9; Seydişehirli’nin benzer yönlerine vurgu yapan bir çalışma için bk. Dilbaz, II. Abdülhamid Döneminde Mektep, s. 74-9).

13 Meşihat Arşivi, nr. 1785, s. 105, 18 Ş 1321/ 9 Kasım 1903.

14 Manastırlı İsmail Hakkı biyografisi için bk. İsmail Kara, "İsmail Hakkı (Manastırlı)”, Yaşamları ve Yapıtlarıyla Osmanlılar Ansiklopedisi, İstanbul: Yapı Kredi Kültür Sanat Yayıncılık, 1999, I, 671-2; Manastırlı'nın muallim portresi ve II. Abdülhamid dönemi eğitim sistemindeki yeri hakkında ayrıntılı bilgi için bk. Dilbaz, II. Abdülhamid Döneminde Mektep, s. 105-7.

15 Bu makalenin 12. dipnotundaki M. Zihni Efendi ve Seydişehirli Mahmut Esad örneklerinin kategorizasyonuna bk.

16 Bu bağlamda yakın dostu İbnülemin’in Giritli Sırrı Paşa için ilk memuriyetlerinde "o zamanlar sarıklı idi” tavsifi hatırlanmalıdır. Taşra bürokrasisinde müfessir ve mütercim bir vali olan Giritli Sırrı Paşa’nın ele alındığı bir çalışma için bk. Dığıroğlu, "II. Abdülhamid Döneminde Dini Yayıncılık”, s. 96-102. 
II. Abdülhamid döneminde dinî eser telif eden ulemanın önemli bir kısmının bürokraside vazife almadan sadece ilimle meşgul olduğu görülür. Müellif ulema içindeki bu grubun ağırlığını oluşturan müderrisler bu makalede dersiam tasnifinde değerlendirildiler. $\mathrm{Bu}$ tasnife tabi olan müracaat sahipleri ilmiyedeki konumları, eserleri ve eserlerinin değerlendirme süreçleri üzerinden ele alınmıştır. Bu süreçleri takip etmek, ulemanın ulemayı tedkik ettiği sahayı keşfetmek anlamına geldiği gibi heyetin müellif ulemanın eserlerini değerlendirme esaslarını da ortaya koyma imkânı sağlayacaktır. Dikkat çeken bir diğer grup ise "talebe-i ulum" sıfatı ile kitap basım ruhsatına müracaat edenlerdir. Dolayısıyla müellif ulema tipolojisini ulema-bürokrat, dersiam ve talebe-i ulum olmak üzere üç ayrı sınıfın oluşturduğu görülmektedir.

\subsubsection{Ulema-Bürokrat}

Müellif ulemanın içindeki ulema-bürokratların ne tür eserler yazdığı ve heyetin bu eserleri nasıl değerlendirdiğine geçmeden önce bu tasnife dâhil olan kimselerin Osmanlı Devleti'ndeki kariyerlerine göz atmak faydalı olacaktır. Eser telif eden ulema-bürokrat, Maarif başta olmak üzere Osmanlı merkez bürokrasisinin çeşitli sahalarında vazife aldığg gibi Meşihat'teki dinî bürokraside de görev almaktadır. Burada başvuruları sebebiyle heyetle muhatap olan ulema-bürokratların kimlikleri, eserleri ve eserlerin denetim mekanizmalarında nasıl değerlendirildiği ele alınacaktır. Maarif Nezareti bünyesinde çalışan ilmiyeli bürokratlardan Dağıstanî Fevzi Efendi, M. Emin [Mekkî] Efendi ve Süleyman Sırrı Efendi’nin eserlerine ruhsat alma girişimleri, ulema-bürokrat başvuru türüne oldukça uygun örneklerdir. $\mathrm{Bu}$ örneklerden ilki heyetten tek seferde onay almış, diğerleri ise tashih ve tadil süreçleri sonunda onay alabilmişlerdir. İlk örneği oluşturan Dağıstanî Fevzi Efendi, hem Meclis-i Maarif ${ }^{17}$ azası hem de Fatih Camii dersiamıdır. ${ }^{18}$ Merkez bürokrasisinde görev alan ilmiye kökenli bir bürokrat olarak Tetkik-i Müellefat Heyeti ile muhatap olmuştur. Fevzi Efendi’nin el-Hediyyetü'l-Medeniyye li'l-kasîdetin-Nebeviyye adlı eseri, Bab-1 Fetva’daki heyetten ilk başvuruda onay almıștır. ${ }^{19}$

Tedkik-i Müellefat Heyeti ile muhatap olan M. Emin [el-Mekkî] Efendi ulema-bürokrat türündeki müelliflerden bir diğeridir. M. Emin Efendi kitap denetim mekanizmasının

Abdülhamid döneminde "Dersaadet ve taşrada mevcud bilcümle müessesat-1 maarifin cihet-i ilmiye ve idaresine müteallik kâffe-i vezâifin merci-i tedkikatı" olarak tanımlanan Meclis-i Kebir-i Maarif'in 1885-1908 yıllarındaki üye dağılımında ilmiyenin dikkat çekici artışına dair kantitatif veriler için bk. Dilbaz, II. Abdülhamid Döneminde Mektep, s. 61-2.

18 Merkez bürokrasideki memuriyetini emekliliğine kadar sürdüren Fevzi Efendi 21 Aralık 1912'de vefat etmiștir. Dağıstanî Fevzi Efendi biyografisi hakkında bk. Sadık Albayrak, Son Devir Osmanlı Uleması, I-V, İstanbul: İstanbul Büyükşehir Belediyesi, 1996, I, 57.

19 Meşihat Arşivi, nr. 1509, s. 43/33; Meşihat Arşivi, nr. 1785, s. 52, 27 Ra 1318/ 25 Temmuz 1900. Baskı onayı aldığı yıl içerisinde İstanbul'da kitabını bastırmıștır. Söz konusu kitap Hacı Hüseyin Efendi matbaasında basılmıștır. Faaliyetlerinin önemli bir kısmını başta Mushaf olmak üzere dinî neşriyat oluşturan bu matbaa ve faaliyetleri hakkında ayrıntılı bilgi için bk. Filiz Dığıroğlu, Dersaadet’te Bir Acem Kitapçı: Kitap-füruş Hacı Hüseyin Ağa, İstanbul: Turkuaz Yayınları, 2014. 
en üstündeki kurumda yani Encümen-i Teftiş’te görev yapmaktadır. Basımına izin istediği Fezâil-i Hulefâ-yı İzâm-ı Osmâniyye ve Haremeyn-i Şerifeyn'de Âsâr-ı Mebrûreleri adlı eseri "işaret edilen mahallerin tashihine itina olunmak şartıyla” onaylanmış ${ }^{20}$ ve ruhsat alır almaz basılmıştır. ${ }^{21}$ Kitabın mahiyeti II. Abdülhamid dönemi din-siyaset ilişkileri bağlamında panislamist/İttihad-1 İslâm politikaları ile oldukça uyumludur. ${ }^{22}$ Osmanlı hilafetini vurgulayan ve Osmanlıların kutsal kentlere yaptıkları hizmetleri anlatan bir eserin dahi ancak denetim mekanizmalarının tasdikinden sonra kabul görmesi son derece şaşırtıcıdır.

Ulema-bürokrat müracaatları içerisinde Encümen-i Teftiş ve Muayene azası Süleyman Sırrı Efendi [Ermenekli]'nin basım izni talebi birçok açıdan kayda değerdir. Birincisi Encümen-i Teftiş ve Muayene, kitap denetim sisteminin en başındaki kurumdur. Dolayısıyla inceleme yapan Meşihat'taki heyetin de bir şekliyle bağlı olduğu Encümen üyelerinden birinin telifatının incelenmesi söz konusudur. Aslında bu durumda M. Emin [Mekkî] Efendi müracaatı ile aynı düzeyde bir muhataplık söz konusudur. ${ }^{23}$ İkincisi Sırrı Efendi'nin 16 Ekim 1890'da fahri olarak atandığı Tetkik-i Müellefat Heyeti vazifesine, Maarif'teki Encümen'e atanana kadar devam etmesidir. ${ }^{24}$ Sırrı Efendi müracaatın değerlendirildiği tarih itibariyle Meşihat’taki komisyondan ayrılmıştır. Ayrıldıktan kısa bir süre sonra Kenzü'l-akâid’e basım onayı için müracaat etmiştir. Merkez bürokratı olarak basım izni istediği Kenzü'l-akâid’i değerlendiren heyet, hiyerarşik olarak kendi kurumuna danışmanlık yapan alt kurullardan biriydi. Bu başvuruyu özel kılan hususlardan birisi Sırrı Efendi'yi kitaplara dair karar veren mekanizmada “özne” statüsünden "nesne” statüsüne geçirmesidir. Bu statü geçişlerini daha da karmaşık hale getiren ise "nesne" statüsüyle muhatap olduğu Meşihat biriminin, Maarif'teki üst kurulunda aktif olarak çalıştı̆̆ı aslında yine bir tür "özne” olduğu dönemde değerlendirme yapılmasıdır.

20 İncelemeyi yapan heyetin "amiri” olan kurumun üyesine bu tür bir yanıtın verilmesi, sistemin herkese eşit ve adil bir şekilde işletildiğine dair iyi bir örnektir (Meşihat Arşivi, nr. 1509, s. 68/14; Meşihat Arşivi, nr. 1785, s. 93, 13 M 1320/ 22 Nisan 1902).

21 Eser Matbaa-i Osmaniye'de basılmıştır. Eserin üzerinde görülen 1318 tarihi, baskı tarihinin Rumi takvim esas alınarak yazıldığını göstermektedir. Ayrıca risâlenin kapağındaki "16 numerolu ve fi 22 Nisan sene 1318 tarihli makam-1 Meşihat-penahinin tasdikini ve Maarif-i Umumiye Nezaret-i celilesiyle Matbuat-1 Dâhiliye Müdüriyet-i aliyyesinin fi 11 Mart sene 1318 tarihli ve on altı numaralı ruhsatname-i resmiyesini haizdir" ibareleri yazar ya da yayıncının Meşihat tasdikini okuyucuya bir kez daha hatırlatmak istediğini göstermektedir. Risâlenin Hilafet Risâleleri antolojisindeki yayımlanmış hali için bkz. Hilafet Risâleleri (haz. İsmail Kara), İstanbul: Klasik Yayınları, 2002, I, 261-280.

22 Bu kitaba dair yorumunun yanısıra İttihad-1 İslâm politikaları çerçevesinde matbuatın da bir araç olarak kullanıldığına ve Abdülhamid dönemi din-siyaset ilişkilerine dair ayrıntılı bilgi için bk. İsmail Kara, "Halife, Sultan, İmparator-II. Abdülhamit Devrinde Din ve Siyaset Meselelerine Dair Birkaç Not”, Müslüman Kalarak Avrupalı Olmak-Çağdaş Türk Düşüncesinde Din Siyaset Tarih Medeniyet, İstanbul: Dergâh Yayınları, 2017, s. 184, 163-191.

23 Aslında bu tür müellif ulemanın Bab-ı Fetva'daki heyet tarafından incelenmesi bürokratik kariyerleri açısından dikey kesişme alanları oluşturmaktadır. Çünkü Bab-ı Fetva’daki heyetin değerlendirdiği kitabın müellifi, söz konusu değerlendirmeyi yapan heyetin bürokrasideki amiri konumundaki Maarif Nezareti’nin birimlerinde çalışabilmektedir.

Musa Alak, "Süleyman Sırrı", DİA, EK-2, 544. 
Sırrı Efendi’nin telif edip basımına izin istediği Kenzü’l-akâid birkaç defa heyetin önüne gelmiş, tashih ve tadil süreci uzun sürmüştür. Kelam ilmine dair olan eser heyet tarafından incelendiğinde içeriğinde yanlışlık ve eksiklikler tespit edilmiş, müellifinin dikkatlice tashih edip yeniden göndermesi tavsiye edilmiştir. Aslında Sırrı Efendỉnin heyetle münasebeti ulemanın ulemayı tashih ve tadile yönlendirdiği tipik vakalardan biridir. Yaklaşık iki yıl sonra kitabı tashih ettiği beyanıyla Sırrı Efendi yeniden başvurduğunda kitap tekrar incelenmiş ve bu defa basım izni almıştır. ${ }^{25}$ Başvurular arasındaki iki yıl, bir merkez bürokratı olarak Sırrı Efendi’nin yoğun mesaisinden ayırabildiği kısa zamanlarda tashihlerle meşgul olabilmesine hamledilmelidir. Kenzü̉l-akâid, basım izni aldığı yıl içerisinde Mahmut Bey matbaasında basılmıştır. ${ }^{26}$ Ertesi yıl Ahter matbaasında gerçekleşen baskı tekrarı da rağbet gören bir eser olduğunu düşündürmektedir. ${ }^{27}$

Heyetin merkezdeki ulema-bürokrata karşı gösterdiği müdekkik tavırdan dinî bürokraside görev yapan bürokrat-âlimler de nasibini almıștır. Meşihat Mektubi kalemi hulefasından Yusuf Suad Efendi’nin ${ }^{28}$ siyere dair yazıp basım ve neşri için ruhsat istediği Mirâtü̧şşuûn adlı kitabın bazı yerlerinin düzeltilip tekrar gönderilmesi gerektiğine ${ }^{29}$ dair karar, dinî bürokraside çalışan ilmiyelilerin bile heyet denetimine takıldığını gösteren bir başka örnektir. Bu sıkı denetim aynı eserin heyetin gündemine birden fazla gelmesine neden olmaktaydı. Örneğin İstanbulî Mehmed Raif Efendi’nin Rûhu'l-kısas adıyla yazdığı eser, dört defa heyet önüne gelmiştir. Kitap içeriğinin karışık ve barındırdığı şiirlerin de karmaşık olması sebebiyle reddedilmiştir. İki yıl boyunca aynı eser üzerinden muhatap olduğu heyete en sonunda Kasâid-i Enbiyâ ismiyle yeniden başvurmuştur. Heyetle uzun süre muhatap olan müelliflerin bulduğu pratik çözümlerin başında eser adında değişikliğe gitmek vardır. ${ }^{30} \mathrm{Bu}$ metodu uygulayan müellif yine de olumsuz yanıt almış olmalıdır. Nihayetinde Hace Raif Efendi, söz konusu kitap hakkındaki kararı bozmak üzere temyiz mahkemesi hüviyetindeki Meclis-i

Meşihat Arşivi, nr. 1784, s. 141, s. 177, 29 S 1313/ 21 Ağustos 1895, 29 Ca 1315/ 26 Ekim 1897.

Süleyman Sırrı, Kenzü’l-akâid, Dersaadet: Mahmud Bey Matbaası, 1315, 109 s.

Süleyman Sırrı, Kenzü'l-akâid - ilm-i kelamdan kenzü'l-akâid nam risâle-i nefise-, 2. bs. Dersaadet: Ahter Matbaası, 1316, 108 s. II. Abdülhamid dönemi din dersi kitaplarını inceleyen Mahmut Dilbaz’a göre kitaptaki "tashih-i akaid" vurgusu, Sırrı Efendi’nin dönem ruhuna uygun bir eser telif ettiğini göstermektedir (Dilbaz, II. Abdülhamid Döneminde Mektep, s. 42, dp. 104).

Meşrutiyet dönemi siyer müelliflerinden Yusuf Suad'ın biyografisi ve siyer teliflerine dair ayrıntılı bilgi için bk. Güllü Yıldız, "II. Meşrutiyet Dönemi Siyer Müellifleri Arasında Geleneğin Sesi: Düzceli Yusuf Suad”, Divan Disiplinlerarası Çalışmalar Dergisi, 201, XV, sy. 29, s. 63-93; a.mlf., "İki Siyer Tek Müellif: Düzceli Yusuf Suad’in Siyer Telifleri”, Otur Baştan Yaz Beni: Oto/Biyografiye Taze Bakışlar (haz. Abdulhamit Kırmızı), İstanbul: Küre Yayınları, 2013, s. $227-262$.

Başbakanlık Osmanlı Arşivi (bundan sonra BOA), Maarif Nezareti Mektubi Kalemi (bundan sonra MF MKT), 429/27, 429/29.

Bu tavır belki eserin içeriğinin değişmesi ile zorunlu bir tercih olarak kitap adının da değişmesinden belki de heyetin önüne yeni bir isimle gitmenin psikolojik avantajından yararlanma isteğinden kaynaklanıyordu. İsim değişikliği ile yapılan bir diğer müracaat örneği olarak Türkzâde Hafız Mehmed Ziyaeddin Efendi’nin tertib ettiği eserin kaydı için bk. Meşihat Arşivi, nr. 1785, s. 60 (15 L 1318). 
Tedkikat-1 Şeriyye'ye ${ }^{31}$ gönderilmesini talep etmek zorunda kalmıştır. ${ }^{32}$ Bu itirazı 1309'da kâtipliğine atandığı meclise yapması, bu tür davalarla ilgili tecrübelerinden kaynaklanmış olabileceği gibi meclisin işleyişindeki tecrübelerine de dayanıyor olabilir. ${ }^{33}$

Heyetle muhatap olan ilmiyeliler arasında "İmam-1 Sani-i Hazret-i Şehriyari-i Esbak" Mehmed Emin Efendi de bulunmaktadır. Padişahların günlük hayatlarında en çok muhatap oldukları kişiler arasında yer alan ve günümüzde imamların yaptı̆̆ 1 vazifelerin hepsini Osmanlı sarayında yerine getiren imâm-1 sultânîlerden ${ }^{34}$ biri olan Mehmed Emin Efendỉnin ilmiye kariyerinin üst mertebelerine eriştiğine şüphe yoktur. Padişahın ikinci imamı Mecmua-i Müfide adlı bir eser tertip etmiştir. "Cem ve tertib” ettiği bu esere baskı onayı almak için müracaat eder. Heyetle bu noktada yolları kesişen padişah imamının müracaatı menfi neticelenmiştir. Heyet, "bir hayli hatayı müştemil olduğu" gerekçesiyle esere basım ruhsatı vermemiştir. ${ }^{35} \mathrm{M}$. Emin Efendi ikinci müracaatında da ruhsat alamamıştır. ${ }^{36}$ Görüldüğü gibi Mehmed Emin Efendi gibi ilmiye teşkilatında önemli bir makama erişmiş, sarayda bizzat Sultan’a imamlık yapmış bir ilmiyeli de heyetin müdekkik incelemesine takılabilmiştir.

\subsubsection{Dersiam}

Heyetle muhatap olan ulemanın önemli bir kısmı ise bürokrasiye girmeden yalnızca ilimle meşgul olan ve bu meşguliyetin doğal bir uzantısı olarak eser telif eden ilmiye ricalidir. Bu kategoride yer alması hiç de şaşırtıcı olmayan ilmiye mensupları elbette dersiamlardır ve eserlerine yayın izni almak için heyet gündemini sık sık işgal etmişlerdir. Dersiam, medreselerde öğrencilere, camilerde halka açık ders verme yetkisine sahip müderris için kullanılan bir unvandır. Özellikle XIX. yüzyılda daha da önem kazanan dersiamların icazet verme yetkisi olanlarına ise "muciz dersiam" denirdi. ${ }^{37}$ Heyetle muhatap olan müderrisler içerisinde "muciz dersiam" sıfatını haiz iki başvuru tespit edilmiştir. Bu başvuru sahiplerinin or-

31 Meclis-i Tedkikat-1 Şeriye hakkında ayrıntılı bilgi için bk. İlhami Yurdakul, Osmanlı Devletinde Şer'i Temyiz Kurumları: Fetvahane-i Ali, Meclis-i Tedkikat-ı Şer'iyye ve Mahkeme-i Temyiz Şer'iyye Dairesi (yüksek lisans tezi 1996), Marmara Üniversitesi Sosyal Bilimler Enstitüsü.

32 “... [kitab] menkûz olarak reddolunduğundan ve ifadât-1 saireden bahisle mezkûr kitabın Meclis-i Tedkikat-1 Şer 'iyeye havale buyrulması müsted'i Raif Efendi...” (Meşihat Arşivi, nr. 1784, s. 64, 15 R 1309/ 18 Kasım 1891). İmâm-1 Sultânîler", İstem, 2006, IV, sy. 7, s. 65-74.

İkinci müracaatında esastan ziyade usûlden reddedildiği görülmektedir. "Risâlenin satır başlarına birçok noktalar vazıyla iade edilmesi üzerine tesadüf eylediği sehv ve görebildiği imla hatalarını tashih ile ol babda tanzim eylediği hata ve sevap cetvelinin takdimiyle görülecek" (Meşihat Arşivi, nr. 1784, s.80, 2 M 310/ 27 Temmuz 1892).

37 Dersiam olabilmek için medreseden mezun olup icazet aldıktan sonra bir imtihana daha girmek gerekiyordu. Dersiamlar cami derslerini umumiyetle sabah namazı ile öğle namazı arasında verirler, halka açık olan bu derslere her kesimden birçok kimse katılırdı. Bu şekilde halka açık ders verme yetkisi alan müderrisler halk arasında oldukça etkili oluyorlard; hatta onların bu nüfuzlarından zaman zaman devlet de faydalanıyordu. Nitekim II. Mahmud, yaptığı sslahatları geniş ölçüde dersiamlar vasitasılyla halka duyurmuștur (Mehmet İpşirli, "Dersiam”, DİA, IX, 1856). 
tak yönü her iki dersiamın da Fatih Camiïnde ders okutmasıdır. Bir diğer ortak yönleri ise icazet vermeleri hasebiyle dönemin birçok âliminin ve dinî bürokratının yetişmesinde hizmet etmiş ve verdikleri icazetlerle klasik medrese sisteminde kalıcı izler bırakmış olmalarıdır. Heyetin değerlendirdiği muciz dersiam başvurularından biri el-Hac Tahir Efendi’ye aittir. Tahir Efendi’nin telif edip izin istediği Zübtedü'l-akâid’e bazı yerleri çıarılmak suretiyle basım onayı verilmiştir. ${ }^{38}$ Diğer müracaat sahibi muciz dersiam Mehmed Eşref Efendi’dir. Eşref Efendi aslında Mısır baskısı olan hanefi fikhına dair bir kitabın İstanbul'da da basılmasını arzu etmiştir. ${ }^{39}$ Söz konusu kitap heyet tarafından istifadeye layık bir eser olarak mütalaa edilmiş ve basım izni almıştır.

Meşhur dersiamlar daha çok selâtin camilerinde veya medreselerin bulunduğu Fatih, Beyazıt, Süleymaniye, Ayasofya ve Nuruosmaniye'de ders okutmuşlardır. ${ }^{40}$ Heyetle muhatap olan müellif dersiamların dağılımına bakıldığında söz konusu tablonun devam ettiği görülmektedir. Nitekim eser telifinde Fatih Camii dersiamlarının yanı sıra Üsküdar dersiamı ve Süleymaniye Camii dersiamı müracaatları da bulunmaktadır. Süleymaniye Camii dersiamı Ali Rıza Efendi’nin Siyelkûtî Tahşiyesi, istifadeye layık eserlerden addedilip basım izni almıştır. ${ }^{41}$ Fatih dersiamlarından Tokadî Mehmed Şerif Efendi’nin hadisleri kolaylıkla bulmak için fihrist suretinde hazırladığı eserin basılmasında bir beis olmadığ $1{ }^{42}$ sudur-1 izamdan Mehmed Fevzi Efendi’nin telif edip basımına ruhsat istediği Fethu'l-verde Şerhu'l-Bürde'nin de "taba münasip olduğu" kararına varılmıştır. ${ }^{43}$ Huzur dersi muhatap ve mukarrirliği de yapan Üsküdar dersiamlarından Vildan Faik Efendi’nin Türkçe kaleme aldığı Esrar-ı Savm risâlesine de ruhsat verilmiştir. ${ }^{44}$ Görüldüğü üzere heyetin incelemeleri, her zaman tashih ve tadil sürecini başlatmamış, olumlu neticelenen birçok örnek de vuku bulmuştur.

Fatih Camii dersiamı Eğinli Mehmed Rahmi Efendi’nin cem ve telif edip basımına izin istediği Tefcîru't-tensim fi kalbi selîm ise heyetin önüne ilk geldiğinde şartlı bir onay alabilmiştir. Yazar itiraz edilen yerleri tashih ederek yeniden başvurduğunda "çizilen mahaller $\mathrm{d}_{1}$ şındakilerin basımının münasip” olduğu kararına varılmıştır. ${ }^{45}$ Velud bir ilmiye mensubu olan Rahmi Efendi başvurusunun dikkate değer bir tarafı da bir sonraki aşamada başvuru-

38 Meşihat Arşivi, nr. 1785, s. 75, 19 Ca 1319/ 3 Eylül 1901.

39 Ukûdü'l-cevahiri'l-münîfe fi edilleti mezhebi'l-İmâm Ebî Hanîfe isimli kitap başvurusu için bk. Meşihat Arşivi, nr. 1784, s. 81, 2 M 1310/ 27 Temmuz 1892.

40 Şemsettin Şeker, Ders ile Sohbet Arasında Ondokuzuncu Asır İstanbulu’nda İlim, Kültür ve Sanat Meclisleri, İstanbul: Zeytinburnu Belediyesi Yayınları, 2013, s. 74-5. Süleymaniye Camii dersiamı Haşim Efendi’nin tercüme eserine ruhsat almak üzere Maarif Nezareti’ne takdim ettiği dilekçe için bk. EK 1.

41 Meşihat Arşivi, nr. 1784, s. 80, 2 M 1310/ 27 Temmuz 1892.

Mirâtü ehâdisil-Buhârî adlı esere dair karar için bk. Meşihat Arşivi, nr. 1784, s. 132, 27 C 1312/ 26 Aralık 1894.

Meşihat Arşivi, nr. 1785, s. 9, 13 Za 1315/ 5 Nisan 1898.

BOA, MF MKT 379/46, 11 B 1315/6 Aralık 1897. Vildan Fâik Efendi hakkında ayrıntılı bilgi için bk. Arzu Güldöşüren, "Vildan Fâik Efendi", DİA, XLIII, 108-9. 
sunu değerlendiren heyetin üyesi olması ve "karar veren" merciine yükselmesidir. Zira eseri için başvurduğu esnada henüz heyet üyesi değildir. Birkaç yll sonra ise uzun süre görev yapacağı Tedkik-i Müellefat Heyeti’nde kitap denetiminin aktörlerinden biri olmuştur.

\subsubsection{Talebe-i Ulûm}

İlmiye sınıfının en alt tabakasını oluşturan "talebe-i ulûm"un ana gayeleri ders takip etmek ve tahsilini tamamladıktan sonra ilmiyede vazife almaktır. ${ }^{46}$ Ancak dinî eserleri inceleyen heyetin kayıtlarına bakıldığında "talebe-i ulûm"dan bazılarının ders takibinin ötesine geçip eser telif ettikleri görülür. "Talebe-i ulûm” sıfatıyla basım onayına müracaat edenlerin bir kısmı İslâm telif geleneği çerçevesinde kendi telif ettikleri eserler için heyet ile muhatap olmuştur. Diğer bir kısmı ise metnine hiç bir şekilde müdahil olmadıkları "kütüb-i mútebere" olarak tavsif edilen kitapların basımına izin almak için başvuruda bulunmuşlardır. Burada "kütüb-i mu'tebere" tabiri bir yönüyle medresede okutulan klasik ders kitaplarına da işaret etmektedir.

Talebe-i ulûmun gerçekleştirdiği iki farklı müracaat türünün daha iyi anlaşılması için bazı talebe müracaatlarına değinmek faydalı olacaktır. Metinlerine müdahil olunmayan kitaplara baskı ruhsatı alma girişimlerine örnek olarak Damad-ı cedid İbrahim Paşa medresesinde ikamet eden talebe-i ulumdan el-Hac Hafız Mustafa Hilmi zikredilebilir. O, Tahtâvînin Hâşiyetü't-Tahtâvî alâ Merâkı'l-felâh Şerhu Nûri'l-îzâh adlı kitabına baskı onayı istemiştir. ${ }^{47}$ Yaklaşık bir ay içerisinde, Meşihat makamının "kütüb-i mu'tebereden" kabul ettiği esere, baskı tekrarı için onay verilmiştir. ${ }^{48}$ Benzer bir talep de talebe-i ulumdan Mehmed Arif Efendi'ye aittir. Bu müracaat ile içlerinde Saçaklızade gibi meşhur medrese ders kitaplarının da olduğu altı kitaba birden baskı onayı istenmiştir. ${ }^{49}$

Osmanlı medrese talebelerinden biri neden Hanefi fikhının meşhur kitaplarından Tahtâvî haşiyesine ya da Saçaklızade gibi medrese ders kitaplarına basım ruhsatı ister? Bu sorunun cevabı hem Osmanlı yayın tarihindeki aktörlerin belirlenmesine hem de dinî neşriyatı yürütenlerin bir kısmının tespitine imkân verecektir. Söz konusu talep bir softanın ticarî

46 Değişik coğrafya ve kültürler içinde yetişmiş, farklı seviyede ve farklı mezhep ve meşrepte hocalara ulaşmak, onların derslerine katılmak, kitaplarını görüp okumak/istinsah yoluyla edinmek, ilmî münakaşa ve münazaralara iştirak etmek, ilmî ve fikrî alışverişlerde bulunmak gibi birbiriyle irtibatlı birçok unsuru içinde barındıran bir faaliyet ve seferler, arayışlar bütünü olarak talebe-i ilm kavramı hakkında bk. İsmail Kara, İlim Bilmez Tarih Hatırlamaz Şerh ve Haşiye Meselesine Dair Birkaç Not, İstanbul: Dergâh Yayınları, 2011, s. 44. İstanbul'da talebe-i ulûm sıfatıyla ders takip eden Rizeli müderris Hafız Kasım Efendi’nin II. Abdülhamid'in son ve II. Meşrutiyet'in ilk yıllarına tekabül eden talebelik serüvenine dair ayrıntılı bigi için bk. Ali Adem Yörük, Müderris ve Hukukçu Rizeli Hafız Kasım Efendi, İstanbul: Dergâh Yayınları, 2014, s. 13-101.

47 Bu ruhsat başvurusu bir talebenin kitap yazma saikleri ve neşretme sebepleri üzerine de bilgiler içerir. Dilekçenin sahibi medreseli softa, Sultan Abdülhamid'in eğitimin yaygınlaştırılması çağrısına uymak maksadıyla söz konusu kitaba ruhsat onayı istediğini ifade etmektedir (BOA, MF MKT 445/57, Lef 1, 25 Mart 1315/ 6 Nisan 1899). 429/29. 
teşebbüsünden ziyade ilmî endişelerine, gayretlerine tekabül ediyor olmalıdır. Yani talebe ders notlarını kitaplaştırmak gayesiyle bu müracaatta bulunmuş gibidir. Belki de bu tür talebe müracaatları ders notlarının/kitaplarının çoğaltılma usûllerinin değiştiğine işaret ediyordur. Kanaatimizce matbaadan önce öğrencilerin ya da hattatların çoğalttığ taplar, artık talebelerin isteği ya da matbaacıların ticarî maksatla basmak istediği eserlerdir. Heyetin önüne incelenmek üzere gelen klasik kaynaklara diğer bir ifadeyle medrese ders kitaplarına basım izni isteyenlerin matbaacı-kitapçı-sahaf esnafından olması da bu durumla yakından alakalı olmalıdır. ${ }^{50}$

Heyetin önüne gelen talebe müracaatlarından bir kısmını şerh-haşiye geleneği çerçevesinde kaleme alınan eserler oluşturur. Talebelerin şerh-haşiye türünde eser telif etmesinin ardındaki en kuvvetli motivasyonun, eser telif ettikleri konuda rüştlerini ispat etmek olduğu hesaba katıldığında, ${ }^{51}$ heyetin önüne gelen talebe-i ulûm müracaatları daha anlamlı hale gelir. Nitekim Mekke-i Mükerreme ahalisinden ve talebe-i ulûmdan Hüseyin Efendi’nin basım onayı istediği eser bu bağlamda değerlendirilebilir. Kenzü̉d-dakâik metni üzerine şerh olarak kaleme aldığı Ahsenü't-tarâik isimli kitaba heyet, "tab'ında itina gösterilmek kaydıyla" onay vermiştir. ${ }^{52}$ Medrese talebeleri sadece şerh-haşiye yazmamış aynı zamanda tercüme de yaparak ilme katkı sağlamışlardır. Heyet kayıtlarında görülen bu tür bir müracaatın sahibi Mustafa Necib Efendidir. Mütercim sıfatıyla yaptığı başvuruda Sirru’s-salât ismini verdiği tercüme eserine onay istemiştir. ${ }^{53}$ Aynı şekilde Aydınlı Mustafa Ferid Efendi de Külliyât-ı Vesâyâ adlı eserine ruhsat istemişse de söz konusu kitabın basım ve neşri uygun görülmemiştir. ${ }^{54}$

Görüldüğü gibi heyetin değerlendirdiği talebe-i ulum müracaatlarından menfi sonuçlanan olduğu gibi müspet sonuçlanan başvurular da vardır. İşkodralı Musa Rıfat Efendi’nin Enfesün-nesâyih'ine izin verilmezken, ${ }^{55} \mathrm{Hac}$ Hafız İsmail Hakkı Efendi’nin Şemâil-i Şems-i Cihân’nın basılması uygun görülmüştür. ${ }^{56}$ Olumlu neticelenen bir talebe-i ulum müracaatı

50 Bu bağlamda matbaacı, kitapçı, sahaf esnafının içerisinde kayda değer örnek olarak iki kitap şirketinin müracaatı zikredilmelidir. Şirket-i Sahafiye-i İraniye kayıtları için bk. Meşihat Arşivi, nr. 1784, s. 79, 88; Şirket-i Sahafiye-i Osmaniye için bk. Meşihat Arşivi, nr. 1784, s. 38; 1785, s. 24, 33, 50, 94_M. Kitabın 'metalaşma’sı kavramı üzerinden Osmanlıda mektep/medrese ders kitapları basmak suretiyle gelişen bir piyasa mekanizmasının varlığına dikkat çeken ve çocuk kitapları/dergileri üzerinden bu tür bir okuma yapan bir çalışma için bk. Fortna, Geç Osmanlı ve Erken Cumhuriyet, s. 227-253.

51 "Şerhle, haşiye ile, talikat ile bir metnin problemini çözen kişi sadece mesleğinin ve yolunun içinde bulunduğu seviyedeki problemlerini çözmüş olmaktan dolayı değil daha yukarıda bir seviyede, daha sistematik ve teferruatlı, daha derin ve bu yüzden ilimle irtibatı gelișmiș ve kuvvetlenmiștir” (Kara, İlim Bilmez Tarih Hatırlamaz, s. 29), "Yüksek seviyeli medrese hocalıklarına doğru tırmanacak olan üstatlarda aranacak şartlar arasında bazen okuttuğu veya okutacağı bir metin için başarılı bir şerh yazması da vardır” (s. 45). Şerh, tedris ve medrese bahsi için ayrıca bk. s. 28-52.

52 Meşihat Arşivi, nr. 1785, s. 110.

53 “... talebe-i ulûmdan Necip Efendi'nin Huşûiyye Risâlesi'nden tercüme ve Sirru's-salât tesmiye...” (Meşihat Arşivi, nr. 1784 , s. 40 , nr. 41 ; s. 26 , nr. 13). 
da Nişancı Mehmed Paşa medresesinde ilim tahsil eden Mustafa Efendi’nin başvurusudur. Heyet tarafından değerlendirilen Bahru'l-edhiyye'nin "tab ve neşri münasip" görülmüştür. ${ }^{57}$ $\mathrm{Bu}$ örneklere ilaveten Süleymaniye'de Darül-hadis Medresesi talebesinden Midillili Abdülcelil Efendi'nin müracaatı zikredilmelidir. Ancak bu müracaat sonucundan ziyade heyetle muhataplık sürecindeki diğer ayrıntılar bakımından ele alınmalıdır. Heyetin gündemine birden fazla - dört defa - gelen talebe-i ulûm müracaatlarından biridir. Fîhi'l-isnầ ve sebîn firka'nın ${ }^{58}$ heyet gündemini mükerrer işgal etmesinin nedeni, içerikten ziyade usûl hatasından kaynaklanır. Kitap isminde yaşanan karmaşayı Abdülcelil Efendi bizzat heyete giderek şifahen verdiği ifade ile düzeltmiştir. ${ }^{59}$

\subsubsection{Merkezin Merkezi: Tedkik-i Müellefat Heyeti Reisinin Tevbe'si}

Üst düzey Osmanlı bürokrasisinin dinî kanadında vazifeli Tedkik-i Müellefat Heyeti’nin başkanı da dinî eser yayınlamak istediğinde aynı prosedürden geçmek zorundaydı. Heyet başkanının başvurusunun incelenme süreci, heyetin son derece müdakkik bir şekilde çalıştığı̆, kararların ilmi müzakereler sonucunda verildiği, her üyenin kanaatini rahatlıkla ifade ettiği bir ortamın resmini çizmektedir. Bu durum II. Abdülhamid dönemi matbuat politikaları literatürüne hâkim olan "sansür paradigmasına" aykırı bir tablo oluşturmaktadır. ${ }^{60}$

Çerkeşşeyhizade Tevfik Efendi’nin başkanlığını yürüttüğg̈ heyet ile müellif sıfatıyla ilk muhataplı̆̆ el-İtkân fi tahkîki'l-imân isimli eserine basım onayı istediğinde başlar. Bu eser heyet tarafından incelenip "şayan-1 istifade" eserlerden biri olarak değerlendirilmiş ve basım izni verilmiştir. ${ }^{61}$ Ancak başkan bile olsanız müracaatınızın her zaman olumlu sonuçlanacağının bir garantisi yoktur. Nitekim Tevfik Efendi’nin Tevbe risâlesi heyetin gündemine geldiği

"Bâb-1 Fetvâpenâhinin tasdikiyle tab` olunmuştur" ifadesi dikkat çekmektedir. Meşihat onaylı bir eser olduğunu kapakta duyurmak yazarın mı yayıncının mı özel tercihi bilinemez ancak okuyucuyu etkilemeye matuf bir politika olduğuna şüphe yoktur. Bir talebe-i ulûm müracaatı neticesinde yayımlanan bu eserin müellifi, tâbíi i ve nâşiri el-Hac Hafız İsmail Hakkı Divriğîdir (bk. EK 2).

57 Meşihat Arşivi, nr. 1509, s. 54/6.

58 Meşihat Arşivi, nr. 1784, s. 85, 99.

59 “...arzuhalde mukaddema tasdik olunan kitabın ismi bâlâsında muharrer olduğu vechile Hâzâ Kitâb fìhi'l-isnâ ve sebîn firka verr-red aleyhim olup kendi tarafından Mürşidü̉d-dâllin ibtalü'l-mudillîn tesmiye eylediğini beyan eylediği gibi heyet-i daiyanemize gelerek şifahen dahi dermiyan eylemesine mebni..." (Meşihat Arşivi, nr. 1784, s. 99, 15 L 1310).

60 Dönem sansürünü keyfi bir biçimde yorumlayan bu hâkim paradigmayı gösteren Jön Türk neşriyatından bir örnek olarak Ahmet Emin Yalman’n 1914’te Columbia Üniversitesi’nde tamamladığı doktora tezi verilebilir: “... Sansürcüler yalnızca 'anayasa', 'istibdat,' 'Mithat Paşa' gibi sakıncalı kelimelerin kullanılmasını engellemekle görevli kifayetsiz insanlardan oluşuyordu” (vurgular bizim) (Ahmet Emin Yalman, Modern Türkiye’nin Gelişim Sürecinde Basın 1831-1913, İstanbul: Türkiye İş Bankası Kültür Yayınları, 2018, s. 64). Bütün Jön Türk neşriyatının yanı sıra bk. Süleyman Kani İrtem, Abdülhamid Devrinde Hafiyelik ve Sansür: Abdülhamide Verilen Jurnaller (haz. Osman Selim Kocahanoğlu), İstanbul: Temel Yayınları, 1999, s. 49, 177-277; Abdülhamid dönemi basın rejimine dair Kani İrtem'den daha soğukkanlı değerlendirmeler yapan bir çalışma için bk. Orhan Koloğlu, Osmanlı Dönemi Basınının İ̧eriği, İstanbul: İstanbul Üniversitesi İletişim Fakültesi 2010, s. 94-114; Abdülhamid dönemi sansür uygulamaları hakkında ayrıca bk. Alpay Kabacalı, Başlangıçtan Günümüze Türkiye’de Basın Sansürü, İstanbul: Gazeteciler Cemiyeti Yayınları, 1990, s. 59-79.

61 Meşihat Arşivi, nr. 1784, s. 71, 3 B 1309/ 2 Şubat 1892. 
ilk seferde tartışmaya yol açmıştır. Nihayetinde heyetin çoğunluğu risâlenin basımında mahzur görmüştür. ${ }^{62}$ Daha sonra Fetvahane'den görüş istenmiş ve yeniden oylama yapılmıştır. ${ }^{63}$ Tevbe risâlesinin içeriğine ya da heyet başkanının müellif sıfatıyla Tedkik-i Müellefat ile muhataplığının serencamına geçmeden önce Çerkeşşeyhizade Tevfik Efendi’nin biyografisinden bahsetmek gerekir.

1242 Receb'inde Çerkeş'de dünyaya gözlerini açan Tevfik Efendi, yirmili yaşlarında "tekmil-i ulûm” için İstanbul'a gelmiştir. Vidinli Mustafa ve Hafız Seyyid Efendilerden okuduğu dersler nihayetinde icazet almış (1269), Anadolu'nun çeşitli şehirlerinde ve Kahire'de görev yapmıştır. Kahire'de görev yaptığı esnada bir divan yayınlamıștır. Daha sonra memleketi Çerkeş’e dönerek on-on iki yll burada hizmet etmiş, okuttuğu yirmi kadar talebeye icazet vermiştir. Bu esnada İcmâl-i İlm-i Nahv, Tahkîk-i İdrâkât, ilm-i sarfa dair Mufassal ve daha birçok mevzuda ilmî eserler kaleme almıştır. İane-i Şehriyye ve Harbiye, İlga-yı Kavaim Komisyonu başkanlığ gibi hizmetlerde de bulunmuştur. 1883 yazında Miftâhu'l-akâid adlı eserini yayınlamıştır. Bir arazi meselesini çözmek üzere görevlendirildiği Aydın vilayetinde Şeyh-i Ekber hakkında Levâyih-ı Kudsiyye ${ }^{64}$ ile Arapça bir eser kaleme alarak İzmir vilayet matbaasında bastırmıştır. İstanbul'a döndügünde Meclis-i Tedkikat-1 Şer'iyye azalığına ilaveten Rumeli Kazaskerliği muavinliği ile Meclis-i Meşayih nezareti uhdesine tevcih edilmiştir. Türkçe olarak kaleme aldığı Tuhfetüss-sıbyan nahv ilmine dairdir. ${ }^{65}$ Meclis-i Meşâyih nazırı iken yayınladığı Meziyyetü'l-İslâm ${ }^{66}$ ile Giritli Sırrı Paşa’nın risâlesine reddiye olarak kaleme aldığ 1 Akâid-i Nesefi Tercümesindeki Yanlşsllklar da basılı eserleridir. ${ }^{67}$ Mantık, kelam ve felsefe konularına dair yazdığı Gâyetül-beyân fi ilmi'l-mîzân adlı eseri Mekteb-i Sanayi Matbaası́nda basılmıştır. Süleymaniye Kütüphanesi’nde yazma nüshası bulunan Ta'zîmü's-sahâbe adlı bir eseri daha bulunmaktadır. ${ }^{68}$ Söz konusu telifatın neredeyse tamamı

62 Meşihat Arşivi, nr. 1784, s. 87, 11 R 1310/ 2 Kasım 1892; s. 90, 2 Ca 1310/ 22 Kasım 1892. Bk. EK 3.

63 Meşihat Arşivi, nr. 1784, s. 94, 11Ş 1310/ 28 Şubat 1893.

64 Risâlenin kapağında 21 Safer 1303/29 Kasım 1885 tarihinde yayınlandığı yazılıdır. Müellifi Tevfik Efendi Levâyihu'lkudsiyye'nin yazılma sebebini İzmir'e gittiği esnada İbnü'l-Mansûrî isminde bir şahısla karşılaştığını, bu şahsın başta İbnü'l-Arabî olmak üzere evliyânın büyüklerini küfürle itham ettiğini, dahası itham etmeyenlerin de kâfir olduğunu söylediğini, bunun üzerine eserini kaleme aldığın belirtir. Tevfik Efendi’nin bu eserini değerlendiren bir makale için bk. Hür Mahmut Yücer, "Bir İbn Arabî Müdafaası: Çerkeşîââe Mehmed Tevfîk Efendi ve Levâyihu'l-kudsiyye fî fedâiliş̧-Şeyhi'l-Ekber adlı Eseri”, Tasavvuf (İbnü’l-Arabî Özel Sayıs1-1), 2008, IX, sy. 21, s. 331-351.

65 Burada özetlediğimiz tercüme-i hali, Çerkeşşeyhizade Tevfik Efendi’nin Kasâid-i Tevfik risâlesinin son kısmında yer almaktadır (Kasâid-i Tevfik, İstanbul: Mihran Matbaası, 1304, s. 46-8).

66 Meziyyetü'l-İslâm, Dersaadet: Mahmut Bey Matbaası, 1306.

67 Giritli Sırrı Paşa (1313/1895) tarafından kaleme alınan Nakdü'l-kelâm fî̀ Akâidi'l-İslâm adlı kitabının tenkid ve tashîhi ile ilgili bir başka risâle daha kaleme almıştır (Yücer, "Bir İbn Arabî Müdafaası...", s. 336).

"Arapça eserine herhangi bir mukaddime yazmayan müellif, hamdele ve salveleden sonra konuya girmiş ve sahabeye hürmet göstermenin vacip olduğunu, ayrıca onlara dil uzatmaktan sakınmak gerektiğini vurgulamıştır. Bu hususun bütün sahabe için gerekli olduğunu, özellikle Aşere-i Mübeşşere konusunda daha hassas olunması gerektiğini belirten müellif, daha sonra ashabın faziletine işaret eden ayet ve hadisleri ele alarak incelemiştir. Sahabe arasında cereyan eden birtakım olayların izahı ve halli üzerinde duran müellif, bu konuları değişik eserlerden nakillerde bulunarak ele almaktadır. En çok nakilde bulunduğu eserler; es-Savâiku'l-muhrika, et-Temhîd, el-Muvâfik, Tathîru'lcenân ve'l-lisân gibi kelâmî eserlerdir. Hz. Ali ve Muaviye ile Hz. Âişe, Talha ve Zübeyr arasındaki olaylar, Yezid ve Hz. Hüseyin olayı en çok işlediği konulardır. Bu hususta Ehl-i sünnet'in görüşünü ön plana çıkarmaktadır" (Yücer, 
Meşihat'taki dinî yayınları inceleme heyeti kurulmadan çok önce yayınlanmıştır. ${ }^{69}$ Velud bir yazar olduğu anlaşılan Tevfik Efendi, 1889 yılında başkanı olduğu Tedkikat-1 Müellefat Heyeti ile müellif sıfatıyla birkaç kez muhatap olmuştur. İlk müracaatında İtkân adlı eserine ruhsat almayı başardığı ifade edilmişti. İkinci başvurusu da kitap olarak neşredilmiş ancak bu risâlenin ilginç bir baskı ve neşir serüveni olmuştur. Bu serüvene dair ayrıntıları Tevfik Efendi’nin olayla ilgili sorgulama esnasında Saray’a verdiği ifadesinde görmek mümkündür.

8 Ekim 1893’te Yıldız Sarayı Mabeyn Başkitabet Dairesi’nde kaleme alınan bir evrakta yayınladığı eser dolayısıyla Meclis-i Tedkik-i Müellefat Reisi Tevfik Efendi hakkında soruşturma açılması istenmiştir. Sarayı rahatsız eden bu kitap neydi? Tevfik Efendi’nin başkanı olduğu inceleme heyeti tarafından "resmen mahzur mütalaa edilerek tasdik edilmeyen" risâleye (Tevbe), yazarı Hamidiye ismini vererek, Mısır’a göndermiş ve orada bastırmıştır. Matbu eserin İstanbul’a gönderildiği, bir kısmının dağıtıldığı, bir kısmının ise dağıtılmak üzere olduğu haber alınmıştır. Meşihat'taki heyet tarafından incelenip tasdik edilmeyen bir eserin tab ve neşri kanunen yasaktır. Tevfik Efendi gibi kazaskerlik payesine ulaşmış bir âlimin bu yasağı delerek eserini bastırması hiç hoş karşılanmamıştır. Bu davranışı nedeniyle Tevfik Efendi hakkında soruşturma başlatılması istenmiştir. ${ }^{70}$

Esasen Ehl-i sünnet çizgisinde bir müellif olan Tevfik Efendi’nin Tevbe risâlesinin içerik dolayısıyla denetime takılması yeterince ilginçtir. Ancak akla gelen ilk soru heyet başkanının onaylanmayacağını düşündüğü eserini Mısır’a bastırıp, ismini değiştirerek gümrükte veya kitapçılarda yapılacak rutin kitap denetimlerinden kurtarmayı mı hedeflemiştir? Baskı yeri ve isim tercihinde içerikten bağımsız endişeler mi taşınmaktaydı? Bu endişelerin başında izin sürecinin uzamasının eserin satış ve dağıtımını olumsuz etkileyeceği mi gelmektedir? İsim değişikliğini de bu endişeye mi hamletmek gerekir? Eserin isminin padişaha atfen "Hamidiye" seçilmesi affa ya da taltife mazhar olma beklentisi olarak mı yorumlanmalıdır? Bab-ı Fetva'da başlatılan incelemede Tevfik Efendi Meşihat’a çağrılarak tevbe hakkında yazmış olduğu risâleyi Mısır'da bastırmasının amacı sorulmuş, kimlerin vasıtasıyla bastırdığı ve özellikle eser ismindeki tercihi sorgulanmıştır. Bu soruşturma dâhilinde sorgulanan bir başka isim ise Tekâyâ müfettişi Muhtar Efendidir. Her ikisinin cevapları yazılı olarak Saray’a sunulmuştur. ${ }^{71}$ Söz konusu risâlenin içeriği Kelamî bir meseleden ibarettir, ancak Osmanlıdaki dinî neşriyatı kontrol eden heyet tarafından bu eserin basımı hususunda "ihtilaf-1 ârâ” ortaya çıımış ve basımına dair tereddüdler dile getirilmiştir. Risâle tevbenin kabulünün Allah üzerine vacip olup olmaması ile ilgili kelamî bir tartışmadan bahsetmektedir. $\mathrm{Bu}$

“Bir İbn Arabî Müdafaası...”, s. 335-6).

69 Beyazıt Yazma Eser Kütüphanesi, Beyazıt Umumi Koleksiyonu’nda bulunan Çerkeşşeyhizade Mehmet Tevfik’e ait Mecmûa-i Resâil'de 14 matbu risâlesi toplu olarak görülmektedir. Kütüphane kayıtlarında 8027/3 künye kaydı ile yer alan bu mecmuanın eser tespit fişinde müellif vakfı olduğu belirtilir.

70 Söz konusu eseri “... nam-1 nami-i şahane ile tevsim etmesi ve bunu Misır’da tab ettirerek neşr eylemesi bir politika maksadına mebni olmak...” üzere yorumlanmasına ve soruşturma başlatılmasına dair bk. BOA, Yıldız Parakende Evrakı Meşihat (bundan sonra YPRK MŞ) 5/19, Lef 3, 27 Ra 1311/8 Ekim 1893. 
tartışmada bütün tarafların görüşleri sıralanırken Mu'tezilî görüş de sıralanmıştır. Heyetteki bazı üyeler eserdeki bu ifadelerde bir mahzur görmezken, bazı üyeler bu ifadelerin yer almaması, bazıları ise ifadelerin tashih edilmesi şartıyla eserin basılması gerektiği yönünde görüş belirtmişlerdir. ${ }^{72}$ Basımına izin verilmeyen eserin Mısır’a kadar gönderilip bastırılması iddiası ve izinsiz olarak isminin padişaha nisbetle "Hamidiye" konması noktasında Meşihat tam bir görüş belirtmemiş, ilmiye ricalinden bir zatın kulluğunun ve padişaha bağl1lığın bir yansıması olarak değerlendirip takdir edilmesi gereken bir tavır olarak yorumlamıştır. Bu yorumun altında Şeyhülislam Mehmed Cemalettin ve Meşihat müsteşarı İbrahim Hakkı Efendilerin imzası bulunmaktadır. ${ }^{73}$

İnceleme çerçevesinde sorgulanan Tekaya müfettişi Ahmed Muhtar Efendi’nin ifadesine göre, Tevfik Efendi bir kitap bastırmak istediğinden bahsederek kendisine Mısır'da tanıdığ1 matbaacı olup olmadığını sormuştur. Matbaacı "Tûbâ?" adlı kimseyi tanıdığını ve bu matbaacının İstanbul'da İbrahim adında bir adamının olduğunu söylemiştir. Tevfik Efendi kitabın bir formasının kaça basılacağını öğrenmek istediğinde, Muhtar Efendi bu soruyu Şeyh İbrahim’e yöneltmiştir. Şeyh İbrahim de Mısır’a mektup yazarak soracağını beyan etmiştir. Gelen cevapla bin nüshanın üç Mısır lirasına basılacağını öğrenen Tevfik Efendi, bastırmak üzere harekete geçmiştir. Bin nüsha bastırılan risâlenin yüz tanesi Mısır'da dağıtılıp geri kalan dokuz yüz adeti, İstanbul’a gönderilerek Tevfik Efendi'ye teslim edilmiştir ${ }^{74}$.

Çerkeşşeyhizade Tevfik Efendi ifadesine, risâledeki isim tercihini açıklayarak başlamıştır. Birçok kitapta ve özellikle Beyrut'ta basılan Şeyh Hüseyin Cisr'in risâlesinde olduğu gibi teberrüken "Hamidiye" ismini koyduğunu ve başka türlü bir maksadı olmadığını ifade eder. Mısır'da basımına Tekâya müfettişi Muhtar Efendi tavassut etmiş ve Hoşkadem Matbaası'nda basılmıştır. ${ }^{75}$ Soruşturmanın ikinci kısmında kitabının mahiyetinden ve başkanı olduğu meclisin bu kitabı değerlendirme sürecinden bahseder. Meclisin iki üyesi (Süleyman Sırrı Efendi ${ }^{76}$ ve Hafız Ahmed Efendi) olumlu görüş beyan ederken diğer üç üye (Rıza Efendi, Yahya Efendi ve Halis Efendi) olumsuz görüş beyan etmiştir. Bunun üzerine Fetvahane'den görüş istenmesine karar verilmiştir. 22 Şubat 1893'de Fetvahane'den kitaba onay verilmiştir. Fetvahaneden onay gelmesine rağmen Tedkik-i Müellefat Heyeti sekiz ay boyunca kitabın basımına onay verilip verilmeyeceğine dair hiçbir resmi tebligatta bulunmamıştır. Nihayetinde ruhsat almış olsa da Tevbe risâlesinin ruhsat alamadığına dair bilginin yayılması ve sürenin uzaması İstanbul'daki matbaalarda basımını güçleştirmiştir. Bu nedenle birçok telifata basımevi olan Mısır matbaalarını tercih etmek zorunda kaldığını ifade etmiştir. ${ }^{77}$

72 Meşihat Arşivi, 1784, s. 87, 11 R 1310/ 2 Kasım 1892.

73 BOA, YPRK MȘ 5/19, Lef 1.

74 BOA, YPRK MŞ 5/19, Lef 6, 29 Ra 1311/10 Ekim 1893.

75 Tevfik Efendi savunmasında risâlenin Mısır'da Hoşkadem Matbaası'nda basıldığını ifade etse de risâlenin sonunda matbaa adı zikredilmeden Kahire’de Hoşkadem semtinde basıldığı kayıtlıdır.

76 Risâle hakkında olumlu kanaat bildiren azalardan Süleyman Sırrı Bey’in bu bölümün başında heyetle birçok defa muhatap olan Kenzü’l-akâid yazarı, Osmanlı ulema ve bürokratı olduğu hatırlatılmalıdır.

77 BOA, YPRK MŞ 5/19, Lef 7, 29 Ra 1311/10 Ekim 1893. İfadesi için bk. EK 4. 
Tevfik Efendi’nin ifadesinde zorunlu tercih olarak belirttiği Mısır’n alternatif baskı merkezi olması, özellikle de payitahtta onaylanmayan fikirlere ve teliflere alternatif oluşturması düşündürücüdür. Her ne kadar baskı izni çıksa, resmi makamlarca risâlesinin içeriği onaylansa da bu sürecin uzamasının eserinin itibarını zedelediğini düşünerek Mısır’ tercih ettiğini söylemesi durumun muğlâklığını ortadan kaldırmaz. Eser nüshalarının büyük çoğunluğunun İstanbul’a getirilmesi eserin İstanbul merkezli okur kitlesi için kaleme alındığını açıkça gösterir. Üstelik Mısır’n illegal birçok yayının basım ve dağıtım merkezi olduğunun bilinmesi, bu tercihi daha da şüpheli kılmaktadır. ${ }^{78}$ Ayrıca kitap adı değişikliğinde örnek aldığı kişi olarak Hüseyin Cisr' in adını zikretmektedir. Cisr' in kaleme aldığı Hamidiye risâlesi ile taltife mazhar olması ve II. Abdülhamid nezdinde "muteber ulema"dan olması da Tevfik Efendi’nin Sultan’a hoş görünme çabaları ya da Sultan’ın meşhur vesveselerinden korunma gayretleri olarak mı yorumlanmalıdır? Kitap adının değişmesi Sultan’ın vesveselerinden korunmaya matuf bir çaba olabilir. ${ }^{79}$ Ancak kitap adının tamamına bakıldığında konunun değişmediği görülecektir. ${ }^{80}$ Daha makul bir yaklaşımla Tevfik Efendi’nin kitap adı değişikliği ve Mısır tercihi, basım onayı sürecinin uzaması ile zedelenen itibarını onarmak maksadına hamledilmelidir. Hatta kitaba itibar kattığı muhakkak olan dört takriz de bu bağlamda değerlendirilmelidir. Risâlenin başındaki takrizler temyiz mahkemesi Reis-i Evveli Seyyid el-Hac Ömer Fehmi Efendi, Medine’nin Şâfiî müftüsü Seyyid Cafer b. es-Seyyid İsmail el-Medenî el-Berzencî, Mekteb-i Nüvvâb’da Mecelle Muallimi olan Mustafa Vehbi Efendi ve Medinetü’s-Selâm’da mezun ve müderris Ömer Sabri Efendi tarafından kaleme alınmıştır.

\subsubsection{Kitap Denetiminde Fetvahane'nin Rolü}

Çerkeşşeyhizade’nin Tevbe'si hakkında Fetvahane’den görüş istenmesi, Fetvahane’nin kitap denetimindeki etkin rolünü göstermektedir. Aslında Fetvahane’nin kitap kontrollerinde yer alması, Meşihat'ta dinî kitap denetimi için kurulan Tedkik-i Müellefat Heyeti’nden öncesine dayanmaktadır. Fetvahane, Tedkik-i Müellefat'ın göreve başlamasından sonra da gerek bu heyetin gerekse Maarif'in doğrudan havale ettiği kitaplar hakkında görüş bildirmiştir. $\mathrm{Bu}$ bağlamda Tedkik-i Müellefat Heyeti’nin Meşihat birimleri içerisinde yoğun mesai yürüteni Fetvahane'dir denilse pek yanlış olmayacaktır. Çünkü Fetvahane'ye havale edilip görüş istenen kitapların sayısı hiç de az değildir.

Havale edilen kitapların içerisinde üst düzey ulemanın da eserleri bulunur. İlginç bir örnek olarak hem heyette hem de Meşihat'in diğer birimlerinde görevli birçok ilmiye mensubunun hocası olan Fatih dersiamlarından Ahmed Hulusi Efendi’nin Fetâvâ-yı Ferâiziyye adlı

78 Mısır'ın muhalif Jön Türk neşriyatına ev sahipliğine dair bk. Ekmeleddin İhsanoğlu, Mısır'da Türkler ve Kültürel Mirasları, İstanbul: İslâm Tarih, Sanat ve Kültür Araştırma Merkezi, 2006, s. 185-6.

79 Mehmet Tevfik Efendinin torunlarından Baha Tanman'dan aktarılan ifadelere dayanarak yapılan bir yorum bizi bu görüşe sevketmiştir: “...yaşlılık yıllarında Ankara'yı çok özlediği ve ziyaret etmek istediği halde, II. Abdülhamid' in malum vesvesesi yüzünden, ailesinin epeyce nüfuzlu olması sebebiyle Ankara’ya gitmesine izin verilmemiştir.” Bu aktarımın ayrıntıları için bk. Yücer, "Bir İbni Arabî Müdafası...” s. 334, dp. 4 (vurgular bizim). 
eseri zikredilmelidir. Hocalarının kitabına onay söz konusu olunca heyet bir üst görüşe daha müracaat etmek istemiş belki de sorumluluğu paylaşmak istemiş ve "konusu itibariyle Fetvahane'ye havale edilmesini" uygun görmüştür. ${ }^{81}$ Bir diğer örnek Fatih dersiamlarından İsmail Efendỉnin tercüme ve telif eylediği Vesâilü'l-felâh fî mesâilin-nikah kitabının değerlendirme sürecidir. Söz konusu eser fikıh bahsine dair olması hasebiyle Fetvahane'den görüş istenmiştir. ${ }^{82}$ Her iki eser için "tab ve neşrinde beis olmadığı" şeklinde görüş beyan edilmiştir. Fetvahane sadece merkez ulemasının değil taşra ulemasının da teliflerini değerlendirmekteydi. Belka naibi Ahmed Cevheri Efendi’nin telif edip tabına ruhsat istediği Fıkh-ı Hanbelî, Fetvahane defterlerinde kaydı bulunan taşra müracaatlarından biridir. ${ }^{83}$ Müelliflerin merkez ya da taşra ulemasından olmasına bakılmaksızın eserin konusu itibariyle fikıh ve fetvaya müteallik olması durumunda Fetvahane'den görüş istenmiștir.

\subsection{Taşra Başvuruları}

Taşrada görev yapan müderris, naip ve müftülerin başını çektiği müellif müracaatlarının incelendiği bu bölümde müellifler hakkındaki veriler, ilmiye ya da bürokrasideki pozisyonlarına göre değil coğrafi dağılımlarına göre sınıflandırılmıştır. ${ }^{84}$ II. Abdülhamid dönemi dinî neşriyatının mecralarını görmek maksadına matuf olarak bu usûl tercih edilmiştir. ${ }^{85} \mathrm{El}-$ bette taşradaki müellif ulema burada görülenden ibaret değildir. Makalede zikredilen taşra uleması, basım izni almak üzere söz konusu prosedürleri işleten ve Tetkik-i Müellefat Heyeti ile muhatap olan müelliflerdir.

\subsubsection{Anadolu}

Tetkik-i Müellefât Heyeti’ne yapılan taşra müracaatları içerisinde müderrisler yoğunluk olarak üst sıralarda yer almaktadır. Müellif müderrislerin bir kısmının dersiam sıfatını haiz oldukları görülür. Heyetin değerlendirdiği bu tür müracaatlardan birisi Konya dersiamlarından Mehmed Efendi'ye aittir. Dersiam Mehmed Efendi, üç eseri için aynı anda ruhsat başvurusunda bulunmuştur. ${ }^{86}$ Eserleri inceleyen heyet sadece ez-Zahîratü'l-kesîre

81 Meşihat Arşivi, nr. 1784, s. 79, 19 Za 1309/ 15 Haziran 1892. Meşihat Arşivi, nr. 379, s. 93A; 31.

82 Meşihat Arşivi, nr. 1784, s. 110, 7 Ş 1311/ 13 Şubat 1894. Meşihat Arşivi, nr. 379, s. 119; 152.

83 Meşihat Arşivi, nr. 379, 105; 17 (23 L 1310); Eseri Fetvahane’ye havale eden Tedkik-i Müellefat Heyeti’nin defter kaydı için bk. Meşihat Arşivi, nr. 1784, s. 100 (22 L 1310).

84 Tedkik-i Müellefat Heyeti’nin kayıtlarına göre taşradan başvuran ulemanın iki kısımdan oluştuğu görülmektedir: Birincisi taşranın kendine mahsus uleması, ikincisi ise vazife icabı taşrada bulunan ulemadır. İkinci kısımdaki başvuru sahipleri doğrudan bölgesel bir özellik taşımasa yani mahallî bir unsurun kitap başvurusu olmasa da nihayetinde bu yapının bir parçasıdır. Ayrıca görevleri esnasında tamamladıkları eserleri için bulundukları coğrafyadan yaptıkları başvuru her halükarda anlamlıdır. Taşra müracaatları doğrudan Maarif Nezareti’ndeki Encümen’e yapılabildiği gibi taşra Maarif müdürlükleri vasıtasıyla da yapılabilmekteydi.

85 II. Abdülhamid dönemindeki dinî eser müelliflerinin taşra dağılımını gösteren harita için bk. EK 7. Bu haritanın hazırlanmasında yardımlarını esirgemeyen kıymetli meslektaşım Yunus Uğur ve Şehir Üniversitesi, Şehir Araştırmaları Merkezi çalışanlarına teşekkür ederim. 
fi mağfireti'l-kebîre adlı esere basım onayı vermis, diğer ikisinin "tab ve neşri caiz olmadığı”nı bildirmiştir. Beypazarı dersiamlarından Naimzade Ahmed Nazif Efendi'ye nazmettiği el-Âsâru'l-vahdâniyye ve'l-envâru's-samadaniyye isimli risâleyi basması için ruhsat verilmiştir. $^{87}$

Heyetin değerlendirdiği taşra uleması kayıtlarından bir diğeri Kastamonu Ziyaiyye Medresesi müderrisi Mehmed Hulusi Efendi'ye aittir. Bu müracaat Hulusi Efendinnin daha önce bastırdığı Kurban Risâlesi'ni bazı ilave ve tashihlerle yeniden bastırmak istemesi sonucunda gerçekleşmiştir. Vilayet üzerinden merkeze gelen talep ${ }^{88}$ değerlendirilerek İlaveli Kurban Risâlesìne ruhsatname verilmiştir. ${ }^{89}$ İlk baskıdan ayrılması, yaptığı tashih ve eklemelerin anlaşılması için metnin başlığına "İlaveli" ibaresini eklemiştir. Heyetin önüne aynı medresede görevli bir başka müderrisin eseri de gelmiştir. Heyet müderrislik vazifesine ilave olarak idadide muallimlik yapan Hacı Ahmed Ziya Efendi’nin yazdığı eseri değerlendirmiştir. Taşra müellif ulemasından Ziya Efendi’nin mektepte vazifeli olması dikkatten kaçmamalıdır. Çünkü değerlendirmeye konu olan Miftâhu'l-felâh'in ders kitabı olması istenmiştir. Ders kitaplarını da inceleyen Bab-ı Fetva'daki heyet sadece kitaba dair görüş beyan etmektedir. Kitabın müfredata alınıp ders kitabı olmasına karar veren nihai merci Maarif Nezaretidir. Nihayetinde Kudûri-i Şerif tercümesi olan bu eserin idadi programına alınması uygun görülmemiş, talep reddedilmiştir. ${ }^{90}$ Müellifin söz konusu kitabı ders kitabı olarak teklif etmesi, daha önce yazdı̆̆ Vesîletü’n-necât'ın uzun süre mekteplerde okutulması tecrübesinden kaynaklanmaktadır. ${ }^{91}$ Görüldüğ̈̈ üzere bu talebin sahibi klasik medrese sisteminden mezun olan bir müderris ve hem medrese sistemine hizmet etmekte hem de modern mekteplerde ders vermektedir. İdadide muallimlik yaptığı esnada medrese talebelerinden oldukça farklı olan mektepli talebe profili ile karşı karşıya kalmıştır. Mekteplilerin okuyacağ ders materyali sıkıntısını bizzat yaşamış bir muallim-müderris olmalıdır. Heyetle muhatap olan müellif ulemanın eser kaleme alma motivasyonları makalenin sınırlarını aşsa da bu örnek üzerinden şu çıkarımda bulunulacaktır: Ahmed Ziya Efendi ihtiyaca bianen Miftâhu'l-felâh'ı tasarlamış ve kaleme almıştır.

87 Dersiam Naimzade’nin "ahlâf-1 ümmete bir yadigâr-1 nacizâne" olarak tanzim ettiği risâlenin baskı izni aldığına dair bk. BOA, MF MKT 481/7, Lef 3, 25 L 1317/26 Şubat 1900. Kütüphane kayıtlarında bu eserini bastırdığına dair bir bilgiye rastlamasak da kayıtlar, Naimzade’nin velud bir müellif olduğunu gösterir. bk. BOA, MF MKT 3/74 (03.C.1289).

89 BOA, MF MKT 481/8, 20 Ş 1317/ 24 Aralık 1899.

90 Kitabın müfredata alınmama sebebi içerikle bağlantılı değil prosedürel bir nedenle açıklanmıștır. “... mekâtib-i idadiyenin bu seneye mahsus olan programları ikmal edilmiş olduğu cihetle Miftâhu'l-felâh'ın mezkûr programa idhaline mahal bulunmadığı...”na dair bk. BOA, MF MKT, Lef 2, 1079/12, 23 Eylül 1324/6 Ekim 1908.

91 Tetkik-i Müellefat Heyeti kayıtlarında Vesîletün-necât müellifi Ahmed Ziyaüddin, Kastamonu Askerî Rüşdiye muallimi olarak anılır (Meşihat Defteri 1785, s.1, nr.66). Bursalı Mehmed Tahir'in "zamanımız ulemasından gayretli bir zat" olarak tavsif ettiği Ahmed Ziyaüddin Efendi’nin Vesiletü’n-necât adlı eseri de senelerce askeri rüşdiyelerde talebenin istifade ettiği bir eser olarak kayıtlıdır (Osmanlı Müellifleri [haz. Ali Fikri Yavuz - İsmail Özen], I-III, İstanbul: Meral Yayınevi, ts., I, 474). 
Heyetin değerlendirdiği Anadolu menşeli müracaatların bir diğerinde Antakya ulemasından Hacı Mehmed Rüşdi Efendi, Mevlid ve Hallü'l-işkâl fi mebâhisi'l-cüz' ve'l-ihtiyâr adlı eserlere ruhsat istemiş ${ }^{92}$ ve ruhsat dilekçesini müellif sıfatıyla imzalamıştır. Bu imza sayesinde Paçacızâde ailesine mensup olduğu ve Meydan Camii müderrisliğini ifa ettiği anlaşılmaktadır. Heyet'in değerlendirdiği eserlerden Mevlid hataları barındırması nedeniyle basım onayı alamazken Hallü'l-işkâl baskı onayı alabilmiştir. ${ }^{93}$ Kütüphane kayıtlarında hemşehrisi Belenli Mesud ile yazdıkları ve müşterek yazılması hasebiyle türünün tek örneği olan bir Müşterek Mevlid kitabı görünmektedir. ${ }^{94}$ Müşterek Mevlid' in heyetin değerlendirip reddettiği Paçacızade’nin Mevlid’i ile bir ilişkisi olup olmadığı tespit edilememiştir. Ancak Paçac1zade'nin heyetten onay alamayan Mevlid kitabından edindiği tecrübeyi, arkadaşıyla beraber kaleme aldığı Müşterek Mevlid in yazımında kullandığı düşünülebilir.

Taşrada müderris dışında en fazla başvuru yapan ilmiye mensupları, kadı ve naiplerdir. Sayıları az olmakla birlikte müftü müracaatları da zikredilmelidir. ${ }^{95}$ Edirne müftüsü $M$. Fevzi Efendi gibi yaşadığı her yıla bir eser yazan ve ardında 75 eser bırakan bir müellif ulemanın heyetle muhatap olmaması düşünülemez. Heyet kayıtlarında sadece Fethu'l-verde şarihi olarak yer alsa da Türk edebiyatında Hz. Peygamber'le ilgili en çok eser verenlerin başında gelir. Nakşî, Halidî, Mekkî koluna bağlı bir sufi olarak hayatını sürdüren M. Fevzi Efendi, son dönem Osmanlı sufi-âlim tipinin müşahhas bir halidir. ${ }^{96}$

Müracaatlar arasında dikkati çeken bir başvuru da Erzurum'dan yapılmıştır. Cafer Efendi Mahallesi Camii hatibi şeyhülkurra Mustafa Niyazi mührüyle verilen dilekçede üç kitap için

92 Meşihat Arşivi, nr. 1509, s. 71/36, 37; Meşihat Arşivi, nr. 1785, s. 91, 23 R 1320/30 Temmuz 1902. "Mevlidi Nebeviyye Tatriki'l-İlhamiyye" isimli eserin ruhsat başvuru dilekçesini "Antalya ulemasından” şeklinde imza atmasına dair bk. BOA, MF MKT 639/46, Lef 1, 28 May1s 1318/10 Haziran 1902.

93 Hallül-işkal'in birkaç baskı yapması rağbet gören bir eser olduğunu göstermektedir: Mehmed Rüşdi, Paçacızade, Hallü'l-işkâl fî mebâhisi'l-cüz'i'l-ihtiyârî, İstanbul: Arif Efendi Matbaası, 1318. 16 s.; Mehmed Rüşdi, Paçacizade, Hallü'l-işkal fî mebâhisi'l-cüz'i'l-ihtiyârî, İstanbul: Mahmud Bey Matbaası, 1320, 16 s.; Mehmed Rüşdi, Paçacızade, Hallü'l-işkâl fi mebâhisi'l-cüz'i’l-ihtiyârî, İstanbul: Mahmud Bey Matbaası, 1321, 16 s.

94 Yegâne nüshası Belenli Mesud'un hattıyla Kayseri Raşid Efendi Kütüphanesi Nr. 152'de kayıtlı olan Müşterek Mevlid, 254 beyti muhteva eden eser Mesnevi tarzında yazılmıștır. Bu eser M. Fatih Köksal tarafından yeni harflerle 2011'de yayımlanmıştır (Mevlid-nâme, Ankara: Türkiye Diyanet Vakfı, 2011).

95 Keskin müftüsü Mehmet Ali Efendi'nin kaleme aldığı Cem'u'l-muhtâr ale’l-Muhtasar, içeriği karmaşık bulunarak baskı izni alamazken (Meșihat Arşivi, 1784, s. 6, 20 S 307/16 Ekim 1889.) Görele müftüsü İbrahim Hilmi Efendi’nin başvurduğu Bustânü'l-ârifîn, bir hayli hata içerdiği gerekçesiyle baskiya uygun bulunmamıştır (Meşihat Arşivi, nr. 1509, s. 36/126; Meşihat Arşivi, nr. 1785, s. 48, 23 M 1318/23 Mayıs 1900).

96 Denizli-Tavas'ta dünyaya gelen Mehmed Fevzi Efendi (1826-1900), Manisa'daki medrese tahsilinin akabinde Anadolu coğrafyası içinde ve dişında müftülük, müderrislik, naiplik, kazaskerlik gibi önemli vazifelerde bulunmuştur. Oldukça velud bir yazar olan Fevzi Efendi, yetmiş beş yil yaşamış ve çoğu küçük risâleler halinde yetmiş beş adet eser kaleme almıştır. Biyografisi için bk. Mustafa Uzun, "Mehmed Fevzi”, DİA, XII, 506-9; Ömer Yılmaz, Mine Oymak, "Edirne Müftüsü Mehmed Fevzî Efendi ve Vesîle-i Saâdet Adlı Eseri / Master Mehmet Fevzithe mufti of Edirne and his work "Vesîle-i Saâdet" (the conducive to happiness)", Turkish Studies (Prof. Dr. Mehmet Akkuş Armağanı), 2016, XI, sy. 17, s. 587. II. Abdülhamid dönemi dinî yayıncılığının konuşulduğu bu zeminde Fevzi Efendi'nin en-Nesâyihu'l-Fevziyye fi'l-ed'iye ve'l-medâyihi's-seniyye adlı küçük risâlesi de anılmalıdır. Çünkü Sultan Abdülhamid'in hilafetini savunmak ve muhalifleri tenkit etmek maksadıyla kaleme almıştır. Bu risâlenin değerlendirmesi ve metin neşri için bk. Hilafet Risâleleri (haz. İsmail Kara), İstanbul: Klasik Yayınları, 2002, I, 22, 253-260. 
ruhsat başvurusunda bulunulmuştur. ${ }^{97}$ Kıraat ilmine ait olan kitaplar Teftiş-i Mesahif'e havale edilir ve kararı orada verilir. Her ne kadar yazar şeyhülkurra da olsa Mushaf meclisinde eserlerine onay verilmez. ${ }^{98}$

Naip başvuruları içerisinde Necâtüll-mükellefin ${ }^{99}$ ve Fütûhu'ş-Şâm Tercümesi ${ }^{100}$ ile Karamürsel eski naiblerinden Şevket Efendi’nin iki eseri değerlendirilmiștir. Necâtü’l-mükellefin ilk incelemede onay alamadıysa da ikinci müracaatında ruhsata nail olabilmiştir. İki ciltten müteşekkil Fütûhu'ş-Şâm Tercümesi ise aslına muvafık olmadığı gibi bazı hataları da barındırdığı gerekçesiyle reddedilmiştir. ${ }^{101}$ Taşra naiplerinden Abdullah Şevket Efendi’nin Necâtü'l-mükellefin dışında bir de Ahlâk-i Dinî isimli eseri basılmıştır. ${ }^{102}$ Eserlerinde ehl-i sünnet anlayışına sıkı sıkıya bağlı olduğu görülen Şevket Efendi, son dönem ahlâk literatüründe ilmiye kanadının muhafazakâr savunucularından biri olarak değerlendirilmektedir. ${ }^{103}$

Taşra müracaatları arasında Urfa naibinin başvurusu tipik ruhsat başvurularından farklı bir yerde durmaktadır. Çünkü Naib Ahmed Faiz Efendi ruhsat verilmiş eserini Halep’te bastırmak üzere tarafına iadesini talep eder. Heyet yaptığı incelemede kitabın birçok yerinin kaynaklara uygunluk derecesini problemli bulmuştur. Bu nedenle Heyet kararındaki vurgu, kaynaklara müracaat edilerek metnin ılah edilmesidir. Nihayetinde kitaptaki hataların tashih edilip, incelenmek üzere tekrar gönderilmesi istenmiştir. ${ }^{104} \mathrm{Bu}$ başvuruda naibin "ruhsat verilmiş" olarak tavsif ettiği eserine ilk onayın hangi kurum tarafından verildiği belirtilmemiştir. Onayı veren kurumun meşkukluğu bir tarafa bırakıldığında da bu müracaat diğerlerinden ayrılmaktadır. Çünkü eserin nerede bastırılacağı ruhsat müracaatlarında pek belirtilmemektedir. Bu bağlamda genel eğilimden farklı olarak Halep’te bastıracağı özellikle zikredilmiştir.

\subsubsection{Hicaz ve Diğer Arap Vilayetleri}

Tedkik-i Müellefat Heyeti’nin gündemine Osmanlı taşrasının Arap yoğunluklu bölgelerinden de talepler gelmiştir. Beyrut, Şam, Mısır ve Hicaz gibi bölgelerdeki müellif ulemanın

97 Söz konusu kitaplar Senedü'l-hıfz, Mürşidü'l-mübtedi ve Tabsıratü'l-müteallimin'dir.

98 Meşihat Arşivi, nr. 1509, s. 42/24; Meşihat Arşivi, nr. 1785, s. 53, 13 Ra 1318/10 Ağustos 1900.

99 İlk inceleme neticesi için bk. Meşihat Arşivi, nr. 1785, s. 53, 13 Ra 1318/ 11 Temmuz 1900. İkinci müracaat dilekçesi için bk. BOA, MF MKT 550/40, Lef 1, 25 Zilkaade 1318/16 Mart 1901.

100 Meşihat Arşivi, nr. 1509, s. 57/31; Meşihat Arşivi, nr. 1785, s. 80, 29 Ş 1319/11 Aralık 1901. Ruhsat dilekçesi için bk. BOA, MF MKT 562/47, Lef 1, 28 M 1319/17 May1s 1901.

101 Şevket Efendi’nin izin dilekçesi için bk. BOA, MF MKT 562/47, Lef 3, 14 N 1319/25 Aralık 1901. “... şu halde tab ve neşri caiz olamayacağı"na dair Meşihat kararı için bk. Lef 3 (14 N 1319).

102 Abdullah Şevket b. Mahmud Hamdi, Necâtü'l-mükellefin, İstanbul: Şirket-i Mürettibiye Matbaası, 1317; İçelli Abdullah Şevket b. Mahmut Hamdi, Ahlak-ı Dinî, İstanbul: Hürriyet Matbaası 1328. Açık künyeleri verilen matbu

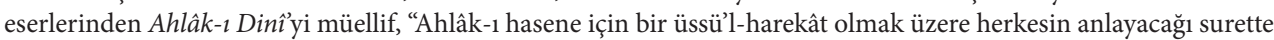
bir eser-i mahsus bulunmadığı”ndan kaleme aldığını ifade etmektedir.

103 Hasan Meydan, "Osmanlı Son Döneminden Ahlâk ve Terbiye’ye İki Farklı Yaklaşım: Abdullah Şevket ve Mehmet Hazık’ın Ahlâk ve Terbiye Anlayışları Üzerine Bir Karşılaştırma”, Tarih Okulu Dergisi, 2017, sy. 29, s. 1-22.

104 Meşihat Arşivi, nr. 1784, s. 15, 28 C 1307/ 19 Şubat 1890. 
talepleri Bab-1 Fetva'daki heyet tarafından değerlendirilmiştir. İlim dilinin Arapça olması hasebiyle dinî eserlerin Arapça telifat üzerinden yürüdügünü söylemeye gerek yoktur. Yine bu bölgelerden gelen eserlerin dinî olsun olmasın Arapça yazıldığını ifadeye de hacet yoktur. Hal böyle iken Hicaz vilayetinden heyete yapılan yegâne başvurunun Kadı Beyzâvî Tefsirìnin Cava lisanına tercümesi ile ilgili olması enteresandır. Talep, Mekke'de basılmış tefsir tercümesinin tekrar baskı onayıyla ilgilidir. Tedkik-i Müellefat Heyeti’nde söz konusu dile hâkim bir üye olmadığ için, şöyle bir tavsiye kararı verilmiştir: Kitap hilafet merkezi İstanbul'a gönderilmek yerine Mekke matbaasındaki musahhihlerin tasdik ettiği nüsha esas alınarak basılmalıdır. ${ }^{105}$

Beyrut matbuat açısından son derece hareketli bir saha olduğu için Beyrut Maarif müdürlüğü, taşra birimleri içerisinde ruhsat alma veya kitap soruşturma işlemlerinde oldukça faaldir. $\mathrm{Bu}$ şekilde Beyrut Maarif müdürlüğ̈̈ vasitasılyla gelen ruhsat taleplerinden birisi Belka naibi Ahmed Cevheri Efendi'ye aittir. ${ }^{106}$ Beyrut vilayetinin ilgilendiği saha içerisindeki bir diğer başvuru da Trablusşam'da el-Mansûrî Cami-i Kebir'i müderrisi Abdüllatif'e aittir. Müderris Abdüllatif Efendi'ye Haşiyetü'l-Düreri'l-cevheriyye ala metni'l-Beykûniyye isimli kitabı basması için ruhsat verilmiştir. ${ }^{107}$ Kayıtlarda Beyrut Bidayet Mahkemesi reisi olarak anılan Yusuf Nebhani'nin eserlerine ruhsat alma girişiminden de bahsedilmelidir. Hadis, tasavvuf ve hal tercümesi sahalarında otorite olan ve kadılık yapan Yusuf b. İsmail Nebhanî (Filistin 1869-Beyrut 1926) tahsilini Ezher'de tamamlamış, bir süre İstanbul'da bulunmuş daha sonra atandığı Beyrut Hukuk Mahkemesi reisliğini yirmi yıl sürdürmüştür. ${ }^{108}$ Birçok eseri olan Nebhani’nin heyet gündemine gelen dört eseri de tek seferde onay almıştır. ${ }^{109}$

Yemen vilayeti aracılığıyla basım izni sürecini başlatan Tabur imamı Mehmed Niyazi Efendỉnin değerlendirmeye konu olan eseri Mevlid ve Mir râc-ı Hazret-i Peygamberî̀dir. Eserini görevi sebebiyle bulunduğu Yemen'de tamamlamış olmalıdır. Tabur imamının heyette incelenen eseri bir hayli hatalı bulunmuş ve reddedilmiştir. ${ }^{110}$ Aynı şekilde Bağdat'taki ordunun süvari alayı imamlığını yaptığı esnada Saadeddin Efendi ruhsat alma girişimini

105 Cava lisanına tercüme edilip Mekke-i mükerreme matbaası musahhihlerinin tasdiklediği Kadı Beyzavi Tefsiri’nin tekrar baskı için Meclis gündemine gelmesi üzerine yapılan yazışma için bk. Meşihat Arşivi, nr. 1785, s.133, nr. 31, 4 C 1323/ 6 Ağustos 1905.

106 Fetvahane kararına rabt edilen Fıkh-ı Hanbelî eserinin ruhsat alma girişimine dair ayrıntılar için bk. Meşihat Arşivi, nr. 1784, s. 100, 22 L 1310/9 Mayıs 1893. Meşihat Arşivi, nr. 379, 105; 17 (23 L 1310)

107 Ruhsat talebi dilekçesi için bk. BOA, MF MKT 336/62, Lef 1, 8 Eylül 1312/20 Eylül 1896; Meşihat kararı için bk. Lef 3, 13 C 1314/ 19 Kasım 1896; Meşihat Arşivi, nr. 1784, s. 157, 27 Ca 1314/3 Kasım 1896.

108 Nebhani hakkında bk. Hilafet Risâleleri (haz. İsmail Kara), İstanbul: Klasik Yayınları, 2002, I, 28; M. Sait Özervarlı, "Nebhani, Yusuf b. İsmail", DIA, XXXII, 471-2.

109 Yusuf Nebhani'nin Tetkik-i Müellefat Heyeti tarafından basımı onaylanan eserleri şunlardır: Huccetullah ale'lâlemîn [fi mu'cizâtı Seyyidi'l-mürselîn], Salavâtü's-senâ [alâ Seyyidi'l-enbiyâ alâ efdali's-salât ve’t-teslîm], Saâdetü'ddâreyn [fi's-salâti alâ Seyyidi'l-kevneyn], İrşâdü'l-hiyara [fî tahzîri'l-müslimîn min medâris'n-Nişara] (Meşihat Arşivi, nr. 1785 , s. 52, 68, 84).

110 Meşihat Arşivi, nr. 1784, s. 139, 25 Z 1312/19 Haziran 1895. 
mahallî maarif müdüriyeti kanalıyla başlatmıştır. Bağdat’taki süvari alayı imamının girişimi Yemen tabur imamınınki gibi olumsuz sonuçlanmamış, baskı için münasip görülmüştür. ${ }^{111}$

Taşra yerel ulemasının telif süreci de heyet defterlerinden takip edilebilmektedir. İstanbul'daki Meşihat makamının azaları, Şam-ı Şerif ulemasından Sefercelânîzâde Emin Efendi'nin el-Kevkebü'l-hasîs şerhu Dürreti'l-hadîs'ine onay vermiştir. ${ }^{112}$ Musul ulemasından Ahmed Fahri Efendi'nin basım izni başvurusu ise nicelik açısından oldukça dikkat çekicidir. Çünkü dokuz eserine birlikte basım izni talep etmiştir. Söz konusu eserler bir süre meclis gündemini işgal etmiştir. Nihayetinde Musullu âlimin dokuz eserinden Kitâbü'l-Ferîd ve Kitâbü's-Seyfi'l-avn adlı risâleleri dışındakilere basım ruhsatı verilmiştir. ${ }^{113}$

\subsubsection{Rumeli}

Tetkik-i Müellefat Heyeti’nin önüne gelen taşra müracaatları içerisinde yoğunluğu en az olan bölge Rumeli vilayetleridir. Taşra müracaatlarının doğrudan İstanbul'a yapılabildiği gibi taşra Maarif müdürlükleri üzerinden de yapılabildiğini hatırlatalım. Ancak Rumeli'de bu tür bir ruhsat girişimine bizzat valiliğin aracılık ettiği görülmüştür. İşkodra valisi Bahri Paşa sorumluluk alanında naiblik yapan Üveys Efendi'nin ruhsat talebini gerekli mercilere iletmiştir. İşkodra merkez naibi Üveys Nail Efendi ruhsat talebini, Mecelle-i Ahkâm-1 Adliye şerhlerinden Tafsîl risâlesine bazı izahlar ve faydalı meseleler ilave ederek hazırladı̆̆ı Sirâcü’t-Tafsîl kitabı için yapmıştır. Bab-ı Fetva'daki heyet her ne kadar fıkıh kitaplarından derlenmiş olsa da bazı ibareleri ve nakilleri anlaşılmaz bulduğundan başvuruyu reddeder. ${ }^{114}$ Muhammed Hilmi'nin el-Ferâidü'l-Hakâniye'si, Bab-1 Fetva'daki heyetin değerlendirdiği Rumeli menşeli müracaatlardan bir diğeridir. Heyet Gümülcine’de Kır mahalle müderrisi Muhammed Hilmi’nin eserine ise şartlı onay vermiştir. Buna göre işaret edilen yerler çıkarılmak suretiyle kitap basılabilecek ve baskıdan sonra bir nüshası da heyete gönderilecektir. ${ }^{115}$ Üsküp müderrisinin baskı onayı istediği Tuhfetü'l-ahvâl risâlesi hakkında "hatiât-1 kesireyi şamil olduğu cihetle tab u neşri caiz olmadığı”na karar verilmiştir. ${ }^{116}$ Prizren naibi Abdüllatif Efendi’nin

111 Meşihat Arşivi, nr. 1509, s. 58, 12 Ca 1319/14 Aralık 1891.

112 Meşihat Arşivi, nr. 1509, s. 20/153; Meşihat Arşivi, nr. 1785, s. 23, 9 Za 316/21 Mart 1899. Suriye Maarif Müdüriyeti’nin tahriratı için bk. BOA, MF MKT 437/4, 23 \$̧ 1316/6 Ocak 1899.

113 Basım izni başvurusunda bulunulan eserlerin adları şöyledir: “Kitâbü'l-Ferîd, Kitâbü's-Seyfi'l-avn, Tuhfetü’l-ebrâr, Vasiyyetü’l-merîd, Ukûdül-mudiyye, Vesîletü'l-müştâk, Nazmü'l-alakat, Mesâil-i Defter?” (Meşihat Arşivi, nr. 1785, s. 49, 12 M 1317/23 Mayıs 1899); aynı defterin 50. sayfasındaki Musullu âlimin başvurusunda Ravzatü’l-mutahhar olarak kayıtlı eser Maarif defterinde Ravzatün-nazır olarak kayıtlıdır (Meșihat Arşivi, nr. 1509, s. 22/8). Musul ulemasından A. Fahri Efendi’ye Ravzatün-nazır isimli fıkıh kitabını basması için ruhsat verildiğine dair Meşihat kararı için bk. BOA, MF MKT 442/65, Lef 4, 27 M 1317/7 Haziran 1899.

114 “...kitabın mündericatı kütüb-i fikhiyyeden cem ve nakl olunmuş ise de bazı ibarât ve menkulâtı anlaşılamayacak derecede tahrif ve ihlal edilmiş ve bazı menkulât dahi kat'a aslına temas etmediği cihetle tab ve neşri gayr-1 caiz bulunmuş olmağla" (Meşihat Arşivi, nr. 1784, s. 23, 26 Ş 1307/17 Nisan 1894).

115 Meşihat Arşivi, nr. 1509, s. 60/59; Meşihat Arşivi, nr. 1785, s. 74, 12 Ca 1319/ 27 Ağustos 1901.

116 Meşihat Arşivi, nr. 1784, s. 126. 
tertib ettiği Tercümân-ı Kudûrî risâlesi de ruhsat alamamıştır. ${ }^{117}$ Rumeli coğrafyasından gelen müellif ulema başvuruları içinde olumlu neticelenen tek müracaat, Sultanyeri eski naibi Bekir Sami Efendi’nin Dürer Gurer tercümesi olmuştur. ${ }^{118}$

\section{Taltife Mazhar ya da Tedkike Maruz Ulema}

Kitabın dünya tarihine dâhil olmasından beri yazılan kitap sebebiyle cezalandırılan yazarlar ya da Sultan başta olmak üzere devlet büyüklerine sundukları kitaplar vesilesiyle ödüllendirilen müellifler var olagelmiştir. Müelliflerin ya da eserlerin her halükarda tedkike maruz kaldıkları II. Abdülhamid dönemi kitap denetim sisteminde, eserler/yazarlar ruhsat alıp almama durumlarına göre bir şekilde otorite tarafından onaylanmış ya da onaylanmamış kategorisine dâhil olmaktaydı. Bu kategoriler matbuat üzerindeki denetimlerin başladığı andan itibaren devreye girmişlerdi. Denetimin Sultan Abdülhamid döneminde başlamamakla beraber onun döneminde oldukça sistemli ve yaygın bir kurumsal örgütlenme şeklinde tezahür ettiği hatırlanmalıdır. İşte bu denetim sistemi içerisinde İslâmî metinleri incelemekle görevli Bab-1 Fetva'daki heyet, kitap değerlerlendirme noktasında tam bir danışma meclisi olarak görev yapmıştır. Bu danışma organının vazifesi, özel olarak kitapların müelliflerini değerlendirmeye/değerlendirtmeye kadar genişletilmiştir. Devletin ilgili birimleri taltif etmeyi düşündükleri yazarların eser içeriğinin bir kez de heyet tarafından gözden geçirilmesini isteyebiliyordu. Heyet herhangi bir talep olmaksızın müellifleri tıpkı kitapları değerlendirdiği gibi inceleyebiliyordu. Tedkik-i Müellefat Heyeti’nin iltifata layık gördüğü müellif ulema örneklerine yakından bakmak hangi müellif ve eserlerin desteklendiğini gösterecektir.

Heyetin kitap değerlendirmenin boyutlarını genişlettiği örneklerden biri olarak Beyrut ulemasından Bekir et-Temîmî en-Nablusînin ruhsat sürecine bakılabilir. Beyrutlu âlim, Protestanların din-i mübin-i İslâm hakkında istihfaf maksadıyla neşr ettikleri er-Ruhbânü’l-Celil adlı kitaba reddiye kaleme almıştır. Nablusînin es-Seyfü'l-Hamidî adlı bu reddiyesi Bab-1 Fetva'daki heyet tarafından değerlendirilir. Heyet'e göre kitap ile hamişindeki Tenvîru'l-ezhân isimli diğer kitap, şayan-1 istifade eserlerden biridir. Müellifi de "taltîf-i âli-i hazret-i meşihâtpenâhîlerine şâyân ulemâ-yı dâiyâneden"dir. ${ }^{119} \mathrm{Bu}$ örnek heyetin eserin ötesinde bir değerlendirmeye gittiğini ve müellifi de değerlendirip övgüye layık bulduğunu göstermektedir.

Taltife mazhar olmakla neticelenen değerlendirmelerden biri de Muş ulemasından Arabzade el-Hac Mehmed Hamdi Efendi’nin baskı izni talebidir. İncelenen Fethu'r-Rahmân, Mecma'u’l-ulûm ve Beyyinül-Kevneyn adlı kitaplar basıma layık bulunur. Ayrıca taltife müstahak olan yazarının da "suret-i münasibede taltif"inden geri durulmaması Meşihat tarafından ifade

117 Hem imtiyazını hem de gelirini Hicaz demiryolu masrafına terk edeceği eserine baskı ruhsatı istediği dilekçe için bk. BOA, MF MKT 785/4, Lef 2, 16 Zilhicce 1321/ 4 Mart 1904; Değerlendirme için bk. Lef 4, 15 Zilhicce 1322/ 20 Şubat 1905.

118 BOA, MF MKT 787/46, 9 R 1322/ 23 Haziran 1904.

119 Meşihat Arşivi, nr. 1785, s. 3, 6 Z 1315/ 28 Nisan 1898. 
edilir. ${ }^{120} \mathrm{Bu}$ tür bir kabul yazar için kitapların devlet tarafından basılma ihtimalini gündeme getirmiş olmalıdır. Özellikle ders kitabı mahiyetinde kaleme aldığı Mecmáu'l-ulûm'un ${ }^{121}$ bu şekilde basılacağını düşünmüşsür. Ancak ilk baskısı 1319 yılında İstanbul'daki Hulusi Efendi Matbaası̉nda yapılan Mecma'u'l-ulûm'u kendi imkânları ile bastırmıştır. Meşrutiyetten sonra bir kez daha ümitlenen müellif, kitaplarının parası olmadığı gerekçesiyle Maarif Nezareti Matbaası'nda basılmasını talep etmiştir. ${ }^{122}$ Kitaplarının son derece faydalı olacağı iddiası da devleti ikna etmemiş olmalı ki talep olumsuz karşılanmıştır. ${ }^{123}$ Ruhsat aldığı eserlerden basılan ilk ve tek eseri olan Mecmáu'l-ulûm, Meşrutiyet döneminde tekrar basılmıştır. ${ }^{124}$

Hilafet merkezi İstanbul tarafından telif ettikleri dinî kitaplar vesilesi ile taltif edilme onuruna erişen birçok âlimden biri Mısır ulemasından Said Efendidir. Telif ettiği fenn-i mantıka ait el-Kavlü'l-eslem fi şerhi's-selem vesilesi ile 5. rütbeden bir kıta Mecidi nişanı ihsanına nail olmuştur. ${ }^{125}$ Trablusşam ulemasından Risâle-i Hamidiye müellifi Hüseyin Cisr Efendi de rütbesi bir derece yükseltilmek suretiyle iltifata mazhar olan ulemadandır. ${ }^{126}$ Osmanlı sınırları dışındaki sünni ulemanın da hilafet merkezi tarafından onandığı görülmüştür. İște bu tür bir hadise Tahran sefiri aracllığıyla Tedkik-i Müellefat Heyeti’nin gündemine giren İranlı sünni bir âlimin eserinde görülmüştür. ${ }^{127}$ İranlı Şemsü’l-ulema Şemseddin Efendi’nin Dav'ü'l-Ebsâr namıyla telif ettiği Arapça risâle değerlendirilir. Hatadan salim olduğu anlaşılan eserin müellifinin de bir nişanla taltifinin münasip olacağı kararına varılır. ${ }^{128} \mathrm{He}$ yetin bu kararı, Şii coğrafyada yaşayan Sünnî bir âlimin hilafet merkezinde taltif edilmesi ile gözetilen birçok siyasetle yakından ilgili olmalıdır. "Cem ve telfik" eylediği kitap sebebiyle müellifi nişana layık bulunan müracaatlardan birisi de Batavyada Umur-1 arabiyye fahri müşaviri olan Seyyid Osman’a aittir. Bu müracaat şöyle gerçekleşir: Maarif Nezareti kitabın kaynakları olan "kütüb-i mu'tebere-i şer'iyyeye" muvafık olup olmadığı ile mürettibi Seyyid

120 Meşihat Arşivi, nr. 1785, s. 20, 6 Ş 1316/ 20 Aralık 1898.

121 “Talebe-i ulûmun mekâtib ve medreselerde duçar olduğu müşkilât ve mufassal mutavvel kitaplarla izâ‘a eyledikleri evkât nazar-1 dikkate alınarak on yedi ilim ve fennin kavâid ve şevâhidini câmi` ve kâffe-i ehl-i ilim ve erbâb-1 tahsile bir hizmet olmak üzre bi-tevfikihi Teâlâ tasnif ve tahrir olunmuştur. İşbu kitabın dikkatle mutalaası halinde kavâid ve şevâhid-i ulûmu mükemmelen görerek ... hâsıl olacağı ve tâlib-i ilm için kifâyet edeceği bî-iştibâhdır" (Mehmed Hamdi Ebü'l-Vefâ b. Abdullah Arapzade, Mecma'u'l-ulûm, Dersaadet: Mercan'da Hulusi Efendi Matbaası, ts.).

122 Talep dilekçesi için bk. BOA, MF MKT 1138/60, Lef 1, 11 Haziran 1325. Ayrıca bk. BOA, DH MKT 951/67.

123 “... kitapların tab'i kendisinin bileceği keyfiyet olduğundan...” (BOA, MF MKT 1138/60, Lef 3, 4 Ağustos 325).

124 Mehmed Hamdi Ebü'l-Vefa b. Abdullah Arabzade, Mecma'u'l-ulûm, Dersaâdet: Hulusi Efendi Matbaası, ts., 319, 19s.; Mehmed Hamdi Efendi, Mecma'u'l-ulûm, Dersaâdet: Hulusi Efendi Matbaası, 1326. 48 s.

125 BOA, İrade Taltifat (Bundan sonra İ. TAL) 49/48 17 L 1311/ 23 Nisan 1894.

126 BOA, Yıldız Parekende Evrakı, Başkitabet (Bundan sonra Y PRK BŞK) 62/10, 18 M 1318/18 Mayıs 1900.

127 Meşihat Arşivi, nr. 1784, s. 50, 21 B 1308/ 2 Mart 1891.

128 “...risâle-i mezkûrenin ibarâtca bazı hatiâtı var ise de mündericâtı rüyet-i Bâri-i Teâlâ hakkında hakkında ulemâ-yı izâmın edillesinin cem'inden ibaret olarak hatadan âri bulunduğu ifade olunmuş mumaileyh Şemseddin Efendi’nin ehl-i sünnet ulemasından bulunmasına nazaran taltifi re’y-i ferman buyrulduğu takdirde münasip rütbeden bir nişan-ı ali ita ve ihsan buyrulması sureti vârid-i hâtır-ı dâiyanem olup..." (BOA, Yıldız Sadaret Hususi Maruzat Evrakı [bundan sonra YA Hus] 244/28, Lef 3, 26 B 1308/ 7 Mart 1891). EK 8. 
Osman’n "şâyân-ı taltîf" olup olmadığını heyete danışır. Bab-ı Fetva'daki heyet, Seyyid Osman’ı ödüle layık müellif olarak değerlendirir. ${ }^{129}$

Nişan ve iltifata mazhar olan müellifler içerisinde Maarif bürokratı M. Zihni Efendiden de bahsetmek gerekir. Zihni Efendi, medrese kökenli olmasına rağmen ilmiyede görev almamış bir bürokrattır. Mehmed Zihni Efendi’nin yazdığı el-Kavlül-mecîd adlı kitaptan dolayı terfi ettirilmesine dair irade sadır olduğunda Mekteb-i Mülkiye-i Şahane usûl-i fikıh muallimi ve Mekteb-i Sultanide edebiyat-1 Arabiye muallimliğinde bulunmaktaydı. ${ }^{130}$ M. Zihni Efendi’nin usûl-1 fikıh, furû-1 fikıh ve Arap diline dair yazdığı ders kitaplarının uzun müddet mekteplerde okutulması iltifata nail olduğunun en açı göstergesidir. Sultana kitap sunma ve takdim edilen kitaplar vesilesi ile taltif edilmenin konuşulduğu bu zeminde, sabık Edirne müftüsü Fevzi Efendi’nin kütüphane-i hümayuna eserlerini takdim etmesi de bir başka örnek olarak zikredilmelidir. Fevzi Efendi hali hazırda ders kitabı olarak okutulan altı kitap ile tefsire dair altı ciltlik kitap olmak üzere toplam on iki cilt kitabını saray kütüphanesine takdim etmiştir. ${ }^{131} \mathrm{Bu}$ takdimin iltifata nail olmak niyetiyle mi yapıldığına ya da müellifin iltifata mazhar olup olmadığına dair bir bilgiye ulaşamasak da yazarların saray kütüphanesine kitaplarını hediye etmesine dair bir tavır olarak buraya kaydedilmiştir.

Müellifin yazdığı kitaba onay beklemenin ötesinde yazdığı kitabın terfisinde etkili olmasını beklediği müstakil örneklere de rastlanır. Nitekim Konya ceza mahkemesi reisi M. Hilal Efendinin müracaatı bu bağlamda zikredilebilir. Müellif risâlesinin " 9 senedir devriye mevleviyetinde” bulunan rütbesini de arttıracağını ümit etmektedir. Benzer bir talep Zile'de Hacımüftüzade Şerif Efendi’nin arzuhalinde de görülmektedir: Telifi olan Menâzimü'l-feraiz'e ruhsat ve kendisinin "terfi-i rütbesi”. Heyet, Şerif Efendi’nin kitabının usûle uygun olduğunu ancak terfi meselesinin kendi birimlerinin meselesi olmadığını ifade eder. ${ }^{132}$

\section{Matbaacı/Sahaf Karşısındaki Müellif Ulema: Telif Hakkı}

Osmanlı matbuat hayatında yazarlar yayınlamak istedikleri eserler için umumiyetle kendileri ruhsat alır, sonrasında bu eserleri istedikleri matbaada bastırırlardı. Yayıncılığın profesyonelleşmesi ile birlikte ruhsat alma prosedürünü yürüten matbaacı/yayıncılar ortaya

129 Meşihat Arşivi, nr. 1509, 40/9; Meşihat Arşivi, nr. 1785, s. 65, 9 M 1318/ 9 Mayıs 1900. İlm-i Mantıktan Fenari Şerhi Hülâsatül-mîzân, İlm-i mantıktan Muğni't-Tüllâb şerhi Seyfill-gullab, İlm-i kelamdan Celâl șerhi Cemal, ilm-i kelamdan Metn-i Celâl șerhi Kenzüll-ferâid, Kurân-1 Kerim’in her bir suresinin ibtidâdaki ayetlerinin tefsirlerine ve kavaid-i sairesine müteallik el-Ünsüll-ma'nevî, Ve’n-Necm suresinin tefsiri Kuddisetü'lİrfan, Sure-i Mülk tefsiri Tesyîru'l-helek, Elem Neşrah Leke suresinin tefsiri Kuddisetü'l-ferâh, İhlas-1 şerif suresinin tefsiri Mesîru'l-halâs, Suret-i Felak tefsiri Tefrî̀ü’l-Felak (BOA, Yıldız Esas Evrakı (bundan sonra YEE) 143/3 [6 R 1327]).

132 Meşihat Arşivi, nr. 1784, s. 39, 28 Ra 1308/ 11 Kasım 1890. 
çıktılar. ${ }^{133}$ Başlangıçta telif ile ilgili meselelerin muğlâk kaldığı Matbuat Nizamnamelerinde zamanla telif haklarının korunmasına yönelik hükümler yer almıştır. ${ }^{134}$ Genel telif hakları ile ilgili düzenlemelerden ziyade burada özellikle dinî eserlerin telif türleri olan şerh, haşiye, talikat gibi eserlerin telif hakları ile ilgili düzenlemeye dikkat çekilecektir. Çünkü matbu dinî eserlerin incelendiği heyetin gündemine gelen müracaatların büyük bir kısmında müellifler kendilerini "tertib eden/mürettib", "cem eyleyen", "tahşiye eden", "telfik eyleyen" gibi sıfatlarla tavsif etmişlerdir. Söz konusu düzenlemeye göre "bir kitabın evvelinden ahirine kadar etrafına ve satırları arasına gerek kendi namına gerek meşâhir-i ulemâ akvâline bi'l-ibtinâen yazılan ve ibârât-1 kitabın teshil-i me ânisi hakkında şerh ve tahşiye kuvvetinde bulunan ta 'likât ve ilavât telif hükm ve kuvvetinde addolunarak mürettibi müellif gibi müstehıkk-1 imtiyaz olacaktır."135

Matbuat ile ilgili düzenlemelerin ayrıntılarının belirlendiği ve yayıncılığın profesyonelleştiği zeminde iş bölümü de netleşmiş görünmektedir. İş bölümünün bir parçası olarak yazarları adına izin alma prosedürlerini yerine getiren matbaacı/yayıncılar, ilmiye mensubu müelliflerine de bu tür hizmetler sunmuşlardır. Bu hizmetin farklı bir boyutu, daha doğrusu telif sıkıntısının yaşanmayacağı bir matbaacı/yayıncı teşebbüsü burada söz konusu edilecektir. Muhaşşa Şerh-i Akaid adlı kitabı tertib eden Beyazıd Cami-i șerifi dersiamlarından Mustafa Efendi, 8 sene önce varisi olmadan vefat etmiştir. Buna binaen kitabın izin prosedürlerini başlatan Sahaf Yusuf Ziya Efendi’nin dilekçesi ile kitap incelemesi başlamıştır. ${ }^{136}$ Maarif Nezareti’ndeki Kütüb-i Diniyye ve Şer'iyye Heyeti’nin ilk incelemesinin ardından Bab-ı Fetva'daki heyetin de incelemesi uygun görülmüştür. Bunun üzerine Meşihat'a gelen eserin tekrar baskı yapmasında bir beis görülmemiştir. ${ }^{137}$ Dersiam Mustafa Efendi’nin eserini sahaf Yusuf Ziya Efendi’nin gönül rahatlığı ile basma yetkisine kavuştuğuna şüphe yoktur.

Hacı Küçük Camii imamı Kayserili Mehmed Nahif Efendi’nin telif ettiği Enîsü'l-âbidîn'in basım izni hikâyesi de tipik bir telif hakkı meselesidir. Enîsü'l-âbidîn 11 Mart 1899'da aldığı baskı ruhsatı üzerine Arif Efendi Matbaası̉nda 17 Haziran 1899'da basılmıştır. ${ }^{138}$ Birkaç yıl sonra Şirket-i Osmaniye müdürü Ahmed Cevdet, Enîsü’l-âbidîn'i basmak istemiş ve müracaatını gerçekleştirmiştir. ${ }^{139}$ Tetkik-i Müellefat Heyeti defterlerinde ve Meşihat'ın Maarif’e gönderdiği tezkirede eserin içerik değerlendirmesinden onay aldığı görülür. ${ }^{140}$ Basımında mahzur yoksa da yazarı Mehmed Nahif Efendi kendi eserinin bir başkası tarafından

133 Yazarları adına yayın prosedürlerini takip eden yayıncı profiline örnek olarak Kitapçı Arakel'in konu edildiği bir çalışma için bk. Dığıroğlu, "İslami Metinleri Kim Üretir?-I”, s. 99-100.

134 Osmanlıda telif hakları ile ilgili ayrıntılı bilgi için bk. Fatmagül Demirel, "Osmanlı Devleti’nde Telif Hakları Sorunu”, Bilgi ve Bellek, 2006, sy. 5, s. 93-104.

135 BOA, Şura-yı Devlet (bundan sonra ŞD), 212/8, 18 Za 1309/ 14 Haziran 1892.

136 BOA, MF MKT 802/65, Lef 1, 19 Haziran 320/ 2 Temmuz 1904.

137 BOA, MF MKT 872/18, Lef 1, 22 Şubat 1320/7 Mart 1905.

138 Kitap kapağı için bk. EK 9.

139 Matbaacının dilekçesi için bk. BOA, MF MKT 618/56, Lef 1, 4 Mart 1317/ 17 Mart 1901.

140 Meşihat Arşivi, 1785, s. 94_M; BOA, MF MKT 618/56, Lef 3, 12 Haziran 1318/25 Haziran 1902. 
basılmasına "rızam yoktur" dediği için matbaacının başvurusu olumsuz cevaplanmıştır. ${ }^{141}$ Şirket-i Osmaniye’nin baskısına rıza göstermeyen Nahif Efendi’nin eseri birkaç yıl sonra Hacı Abbas Efendi Matbaası̉nda basılmıştır. ${ }^{142}$ Birkaç sene sonra İlaveli Enîsüll-âbidîn ismiyle başka bir matbaada yeniden bastırdığı kitabın iç kapağında, satış yeri olarak oğlunun kitapçı dükkânını işaret etmiştir. Eserin kapağında okuyucuları ile telif tecrübesini paylaşan müellif, "taklid kitap" hikâyesinden de şöyle bahsetmiştir: ${ }^{143}$

"Lütf-1 Bâri ile akdemce telifine muvaffak olduğum Enîsüll-âbidîn nam risâlem mazhar-1 kabul-i âmme olarak neşri tekessür ettikçe bazı garazkârânın menâfi-i şahsiyyeleri için kanunun bahş eylediği kırk sene imtiyaz-1 te'lifiyye ve hakk-1 sarihama tecavüz ve kitabımı taklid ederek sıhhatini de ihlal eylemişlerdi. Bu kere âcizleri tarafından bi-avnihi Teâlâ aslından fazla 500'e karib mesâil-i diniyye ve vezâif-i İslâmiyye cem've derc olunarak ve Meşihat-1 uzmâ Tedkik-i Müellefât-1 Şer'iyye heyet-i muhteremesince de tedkik ve tasdik edilerek İlaveli Enîsü'l-âbidîn namıla intişarına muvaffak olduğumdan yine her hukuku bana ve evladlarıma aid olacağı ahkâm-ı kanuniyyeden olmağla bu ihtarım ve mührüm olmayan nüshalara sahte nazarıyla bakılacağı ve mukallidlerinin de kanunen mesul tutulacağı ihvan-1 dine ihtar olunur".

\section{Sonuç}

$\mathrm{Bu}$ makalede II. Abdülhamid döneminde müellif ulemanın siyasî, bürokratik ve sosyal yapıdaki yeri ve pozisyonu incelenmiştir. Tetkik-i Müellefat Heyeti kayıtları üzerinden yapılan bu incelemenin vardığı ilk sonuç müellif ulemanın çeşitliliğidir. Kayıtlarda bürokratlık yapan üst düzey ilmiye ricalinin eser telif etme gayreti kadar medrese eğitiminin esas taşıyıcıları olan dersiamların da telifatı göze çarpmaktadır. Bunların yanı sıra ilmiyenin en alt tabakasını oluşturan "talebe-i ulûm" müracaatları da kayda değer bir bileşen olarak müellif ulema içerisinde yer almaktadır.

Makalenin önemli bulgularından bir diğeri ise müellif ulemadan bazılarının kariyer çizgisinde enterasan kesişmeler olduğudur. Bu kesişmenin alt düzeydeki yansıması, müellif sıfatıyla muhatap oldukları/olacakları Bab-1 Fetva'daki heyetin üyesi olmaları ile ortaya çımaktadır. Bu durum Eğinli Mehmet Rahmi Efendi gibi bazılarını denetim mekanizmasının "karar verilen" nesnesinden "karar veren” öznesine doğru evirirken heyet başkanı Çerkeşşeyhizade Tevfik Efendi gibi bazılarını da özneden nesneye doğru evirmiştir. Söz konusu kesişmenin üst düzeydeki yansıması ise Bab-1 Fetva'daki heyetin görüş bildirdiği Maarif Encümeni’nde görevli ulemanın müellif sıfatıyla tedkike maruz kaldığında görülmüştür. Süleyman Sırrı Efendi’nin Kenzüll-akâid değerlendirmesi bu kesişmelerin üst düzey yansımalarına

141 BOA, MF MKT 618/56, Lef 3, Evrak arkası (20 Haziran 1318/3 Temmuz 1902).

142 Muhammed Nahif b. el-Hac Ahmed Kayseri, Enîsül-âbidîn, Dersaâdet: Hacı Abbas Efendi Matbaası, 1323,168 s. 
güzel bir örnektir. Bu kesişmelerin gösterdiği diğer bir husus ise kitap denetimlerinin, herkese eşit mesafede adilane suretle yapılmakta olduğudur. Bu bulguyu kanıtlayacak birçok örneğin yanısıra denetimlerin merkezindeki Tedkik-i Müellefat Heyeti başkanının ruhsat alma girişimi özellikle hatırlanmalıdır.

Elinizdeki çalışma Bab-1 Fetva'daki ilmiye ricali tarafından dinî kitapların ve müellifleri olan âlimlerin nasıl tedkik edildiğini ele almıştır. Ancak makalenin öncelikli meselesi heyetin hangi gerekçelerle eserlere onay verip vermediğini anlamak değildir. Buna rağmen tespit edilen gerekçeler zikredilmiştir. Bu tespitler ulemanın ne tür durumlarda devlet denetimine takıldığını göstermesi bakımından kıymetli olması bir tarafa denetimden geçebilenlerin "makbul ulema mı sayıldığı" türündeki bazı sorulara da yanıt oluşturabilir. Makalenin bu ve benzeri birçok yeni sorunun cevaplanmasına temel oluşturacağı ve katkı sağlayacağı umulmaktadır. Yine bu makale çerçevesinde dişarda bırakılan müelliflerin kitap telif etme motivasyonları ya da ulema-bürokrat, müderris, müftü, naib gibi müellif ulema türlerinin ürettiği metinler arasındaki benzerlik ve farklıklar meseleleri de yeni araştırmaları bekleyen konular olarak zikredilmelidir. 
EK 1: Süleymaniye Cami-i şerifi dersiamlarından Haşim Efendi’nin tercüme ettiği Takrirü’l-Celâl adlı esere basım ruhsatı almak üzere Maarif Nezareti’ne takdim ettiği dilekçe (BOA, MF MKT, 839/10).

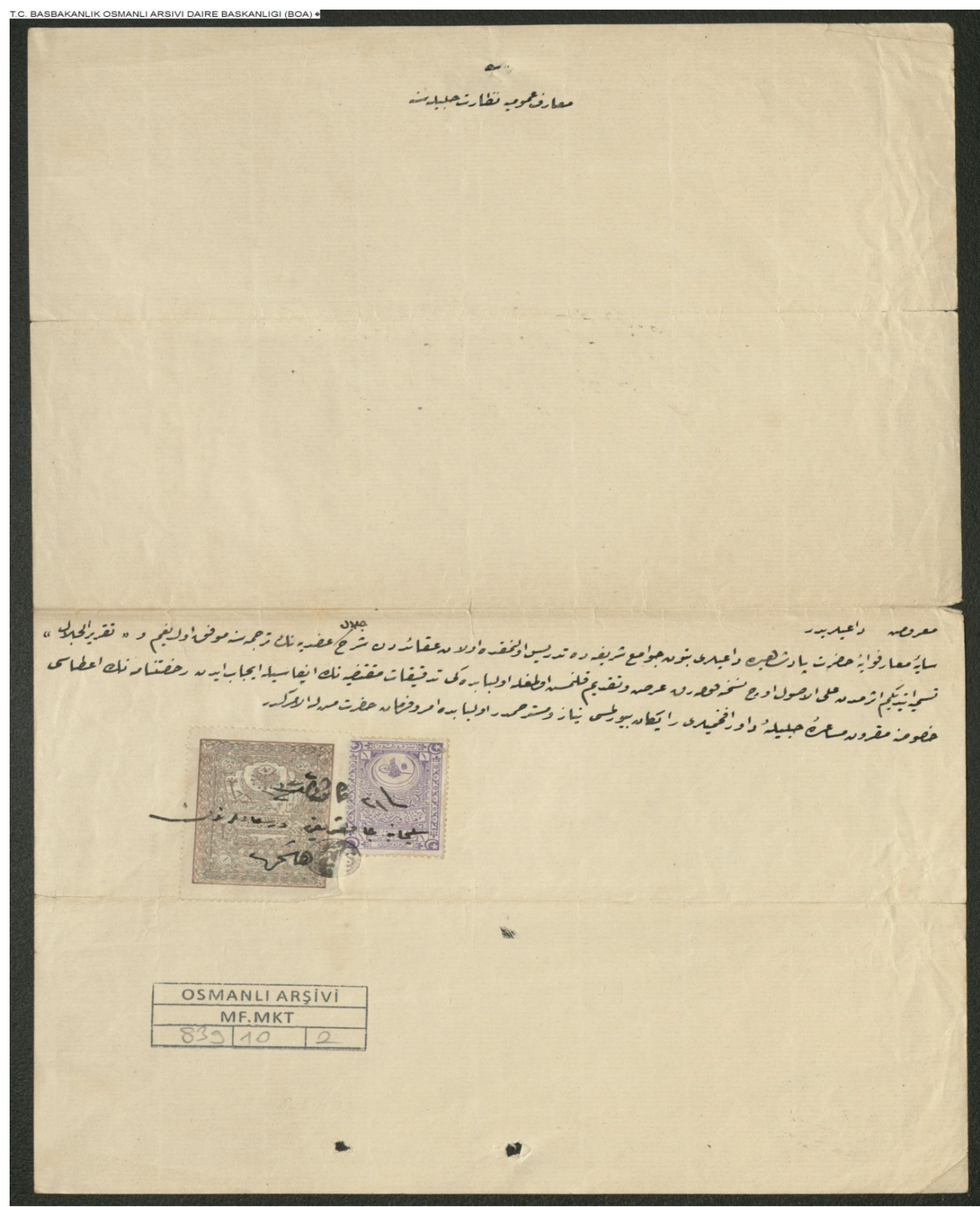

MF.MKT.00839.00010.002 
EK 2: Talebe-i ulûm'dan birinin müracaatı neticesinde yayımlanan Şemâil-i Şems-i Cihân. Eserin müellifi, tâbi'i ve nâşiri el-Hac Hafız İsmail Hakkı Divriğî̀dir.

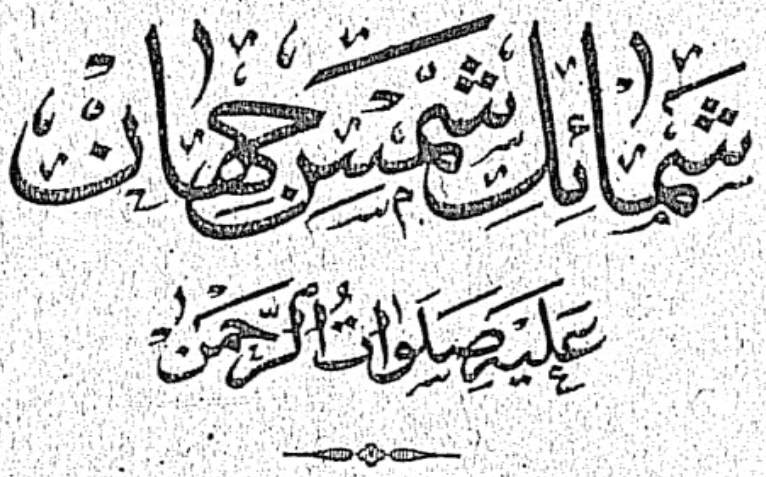

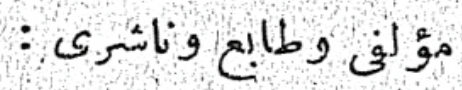

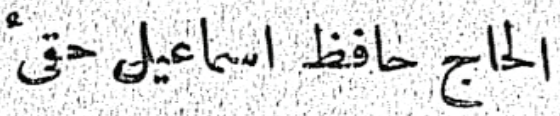<smiles></smiles>

soe

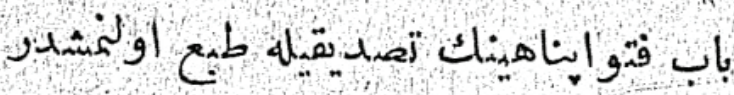

Cก) 5

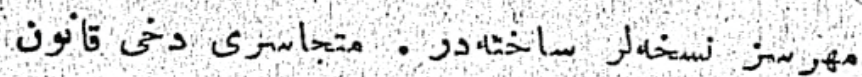

Jugine atulde

تصlows

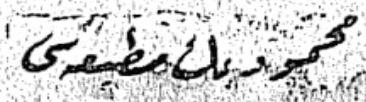

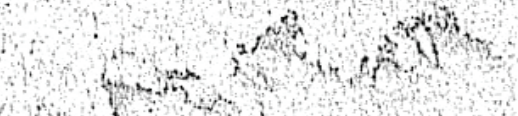

$1+49$

in

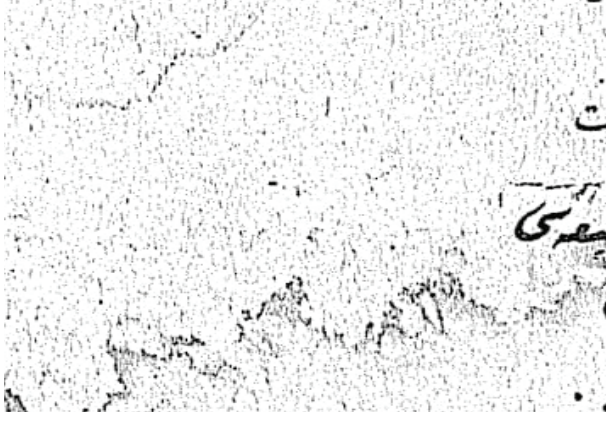


EK 3: Çerkeşşeyhizade’nin tevbe hakkında kaleme aldığı risâleye dair Tetkik-i Müellefat Heyeti'nin değerlendirmesini gösteren karar defteri sayfası (Meşihat Arşivi, nr. 1784, s. 87).

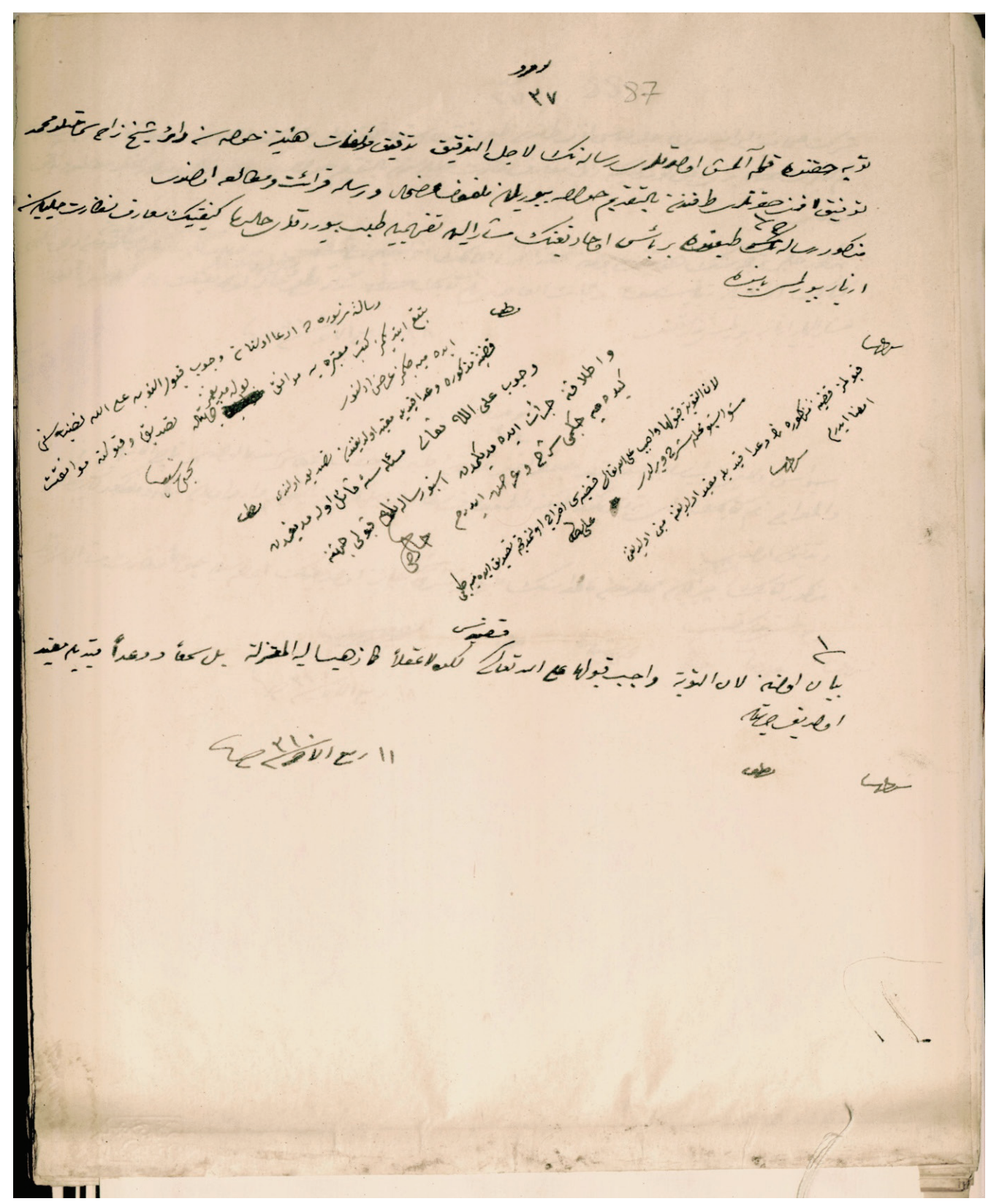


EK 4: Çerkeşşeyhizade Tevfik Efendi’nin kitap soruşturmasına dair verdiği yazılı ifade (BOA, YPRK MŞ $5 / 19$, lef 7).

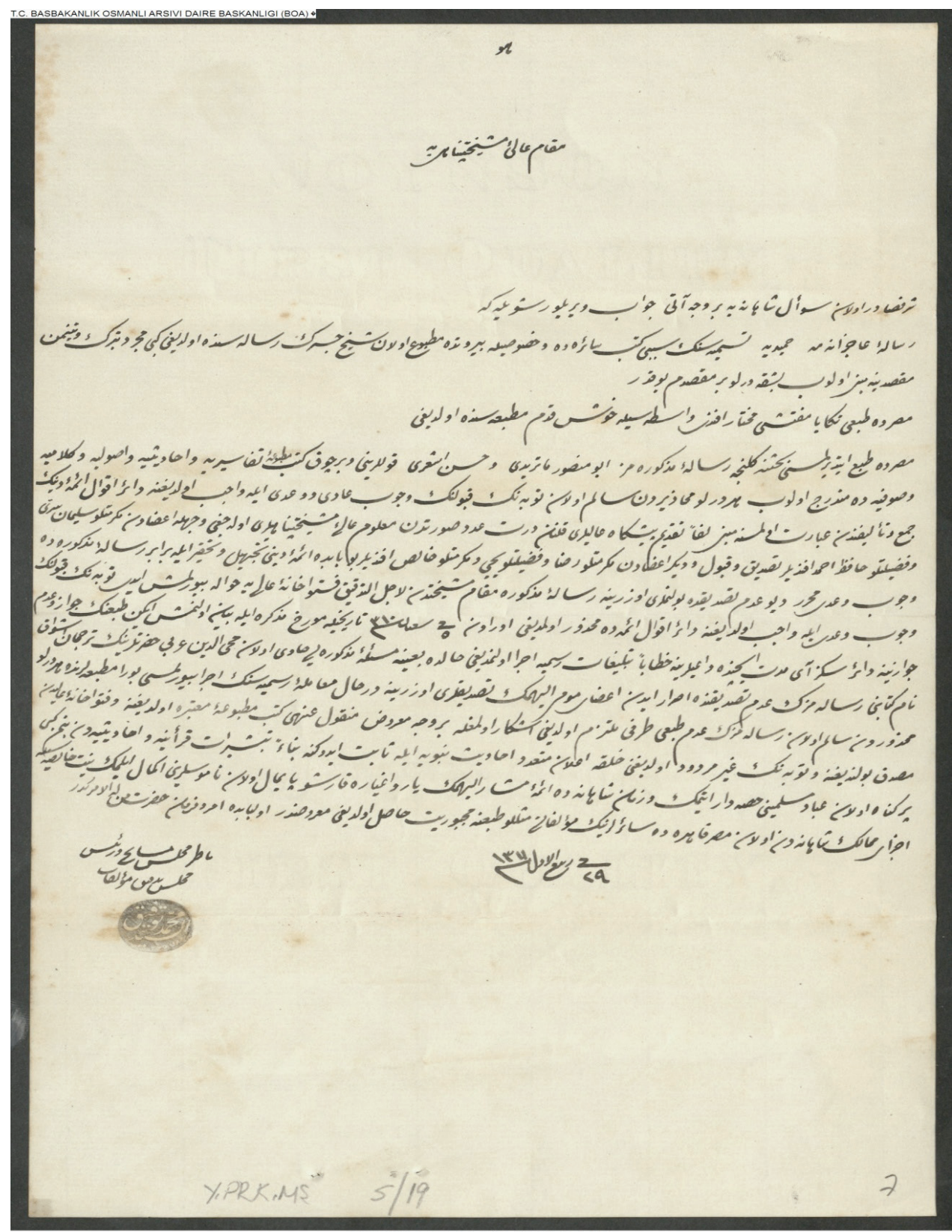

Y.PRK.MŞ.00005.00019.007 
EK 5: er-Risâletü'l-Hamidiye'nin iç kapağı

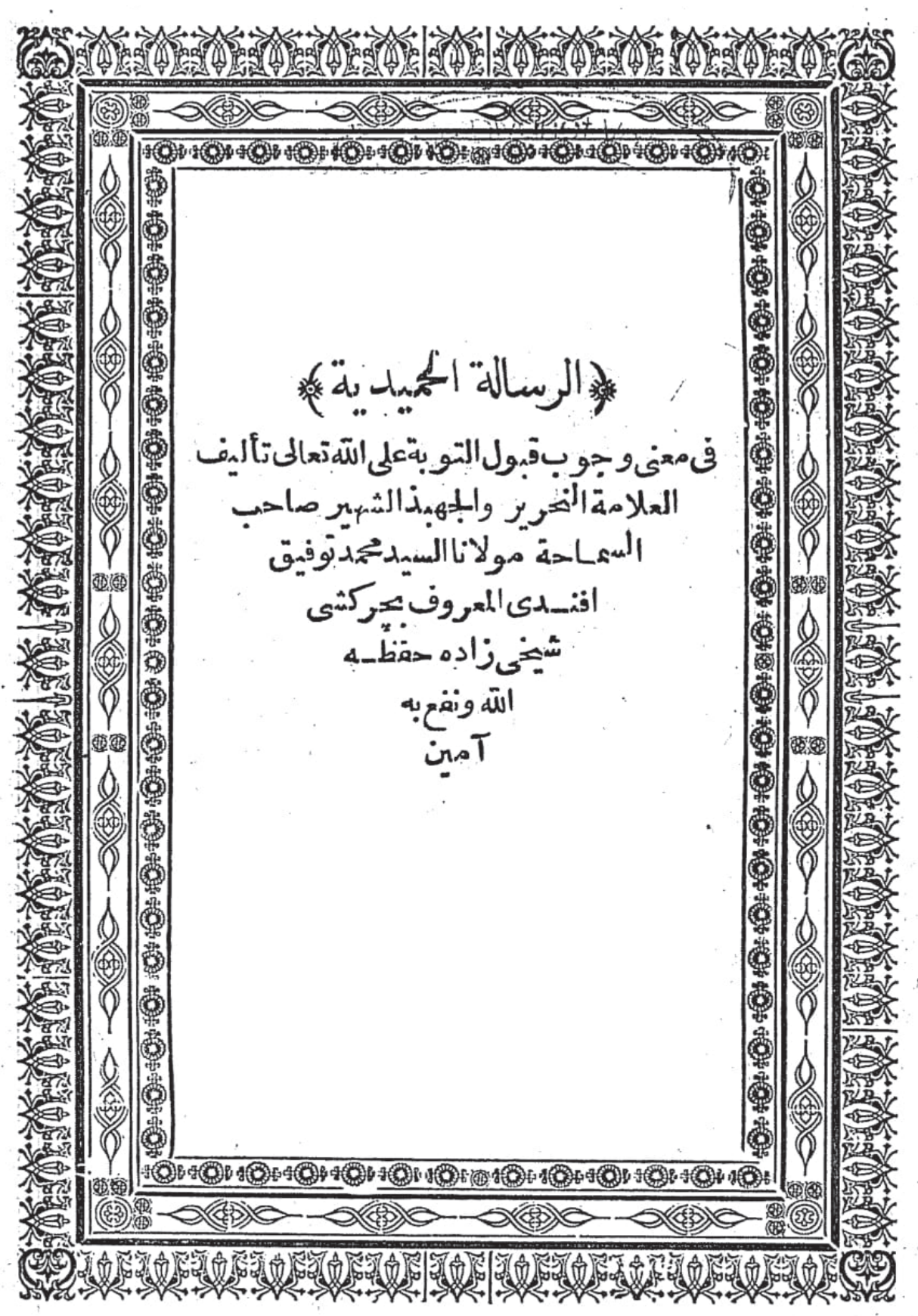


EK 6: Tevfik Efendi'nin er-Risâletü'l-Hamidiye adlı eserinin oğulları tarafından Kütüphane-i Umumi’ye bağışlanan nüshalarından biri.

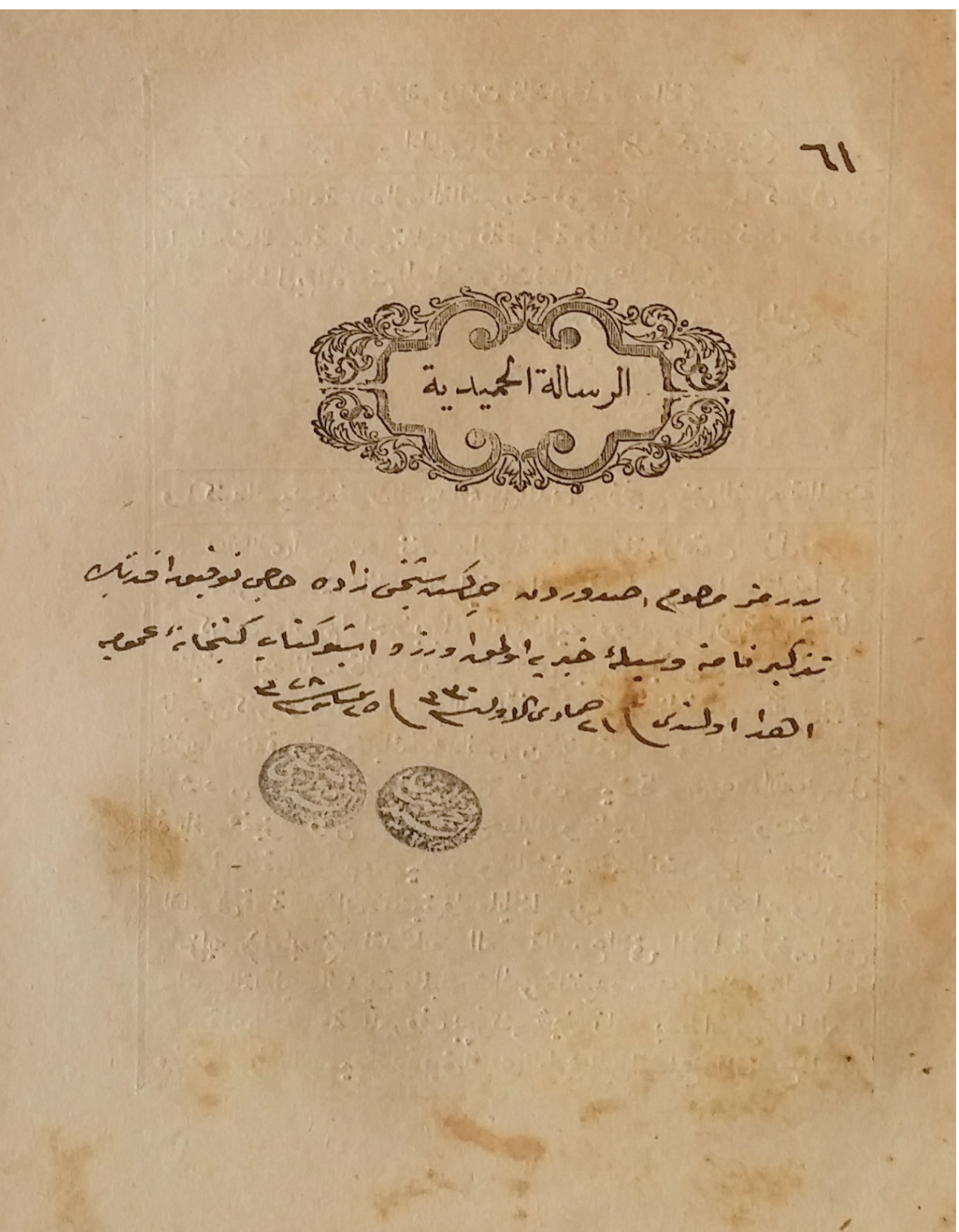


EK 7: Dinî Eser Müelliflerinin Taşra Dağılımı Haritası (1889-1906).

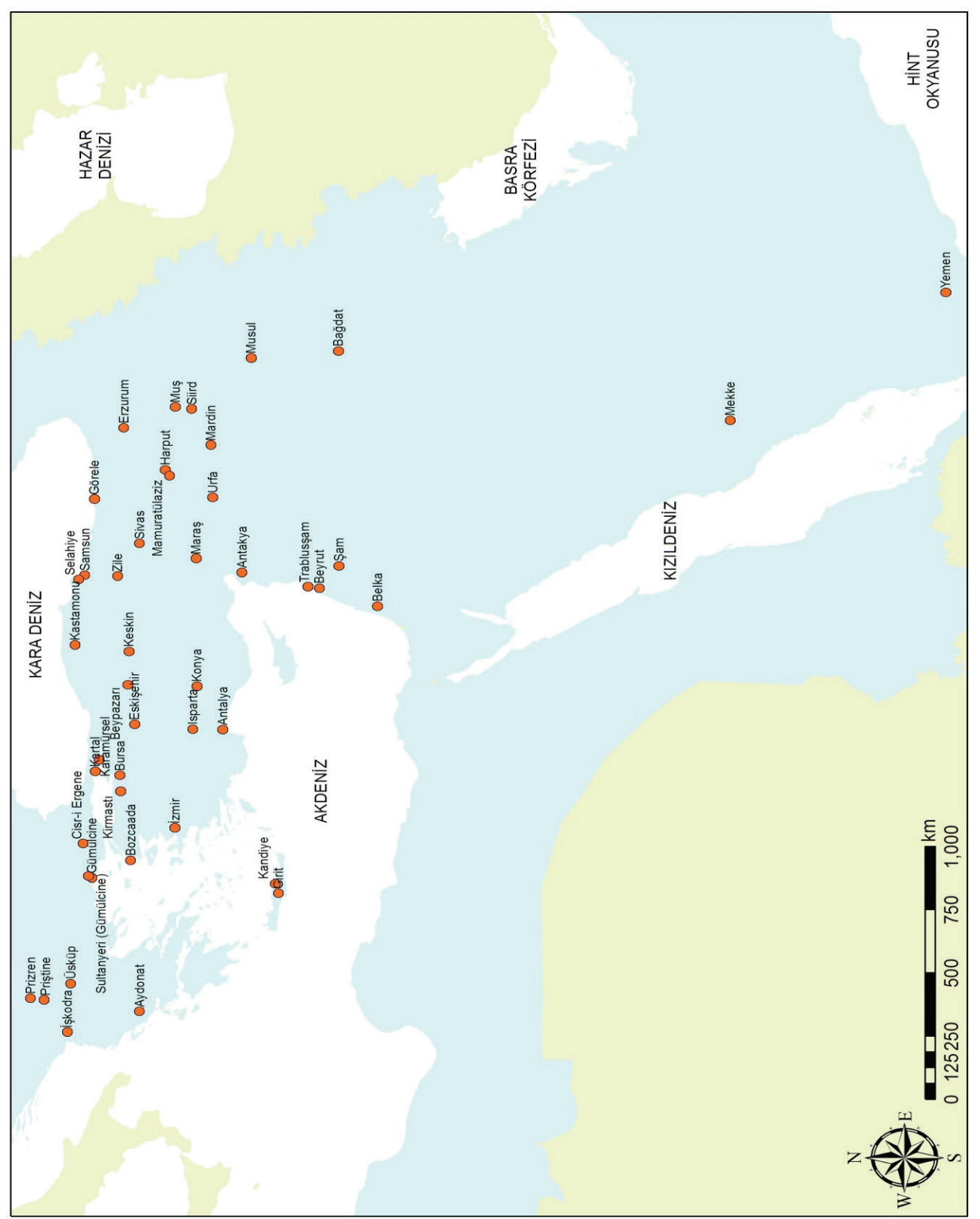

Kaynak: Bab-1 Fetva, Tetkik-i Müellefat Heyeti Defterleri 1784-1785. 
EK 8: İranlı ulemanın taltifine dair evrak (BOA, YA HUS 244/28, Lef 3).

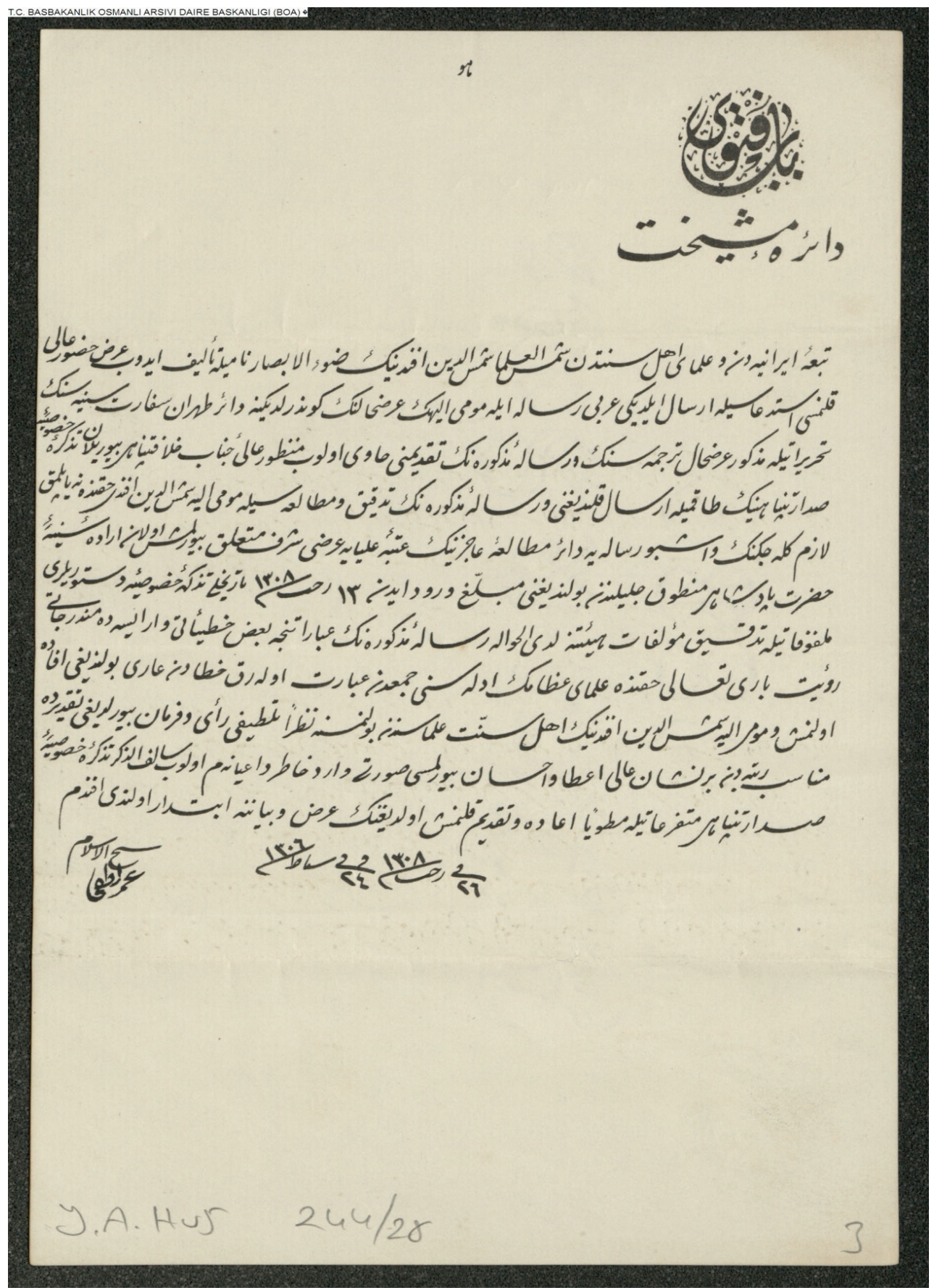

Y.A.HUS.00244.00028.003 
EK 9: Telif meselesi ile gündeme gelen Enisü’l-Abidîn adlı eserin kapağı.

Kapaktaki "Makam-1 Meşihat-1 uzmâ Tetkik-i Müellefât Heyeti’nin tedkik ve tasvibi ... ile... tab` olunmuştur” ifadeleri dikkat çekmektedir.

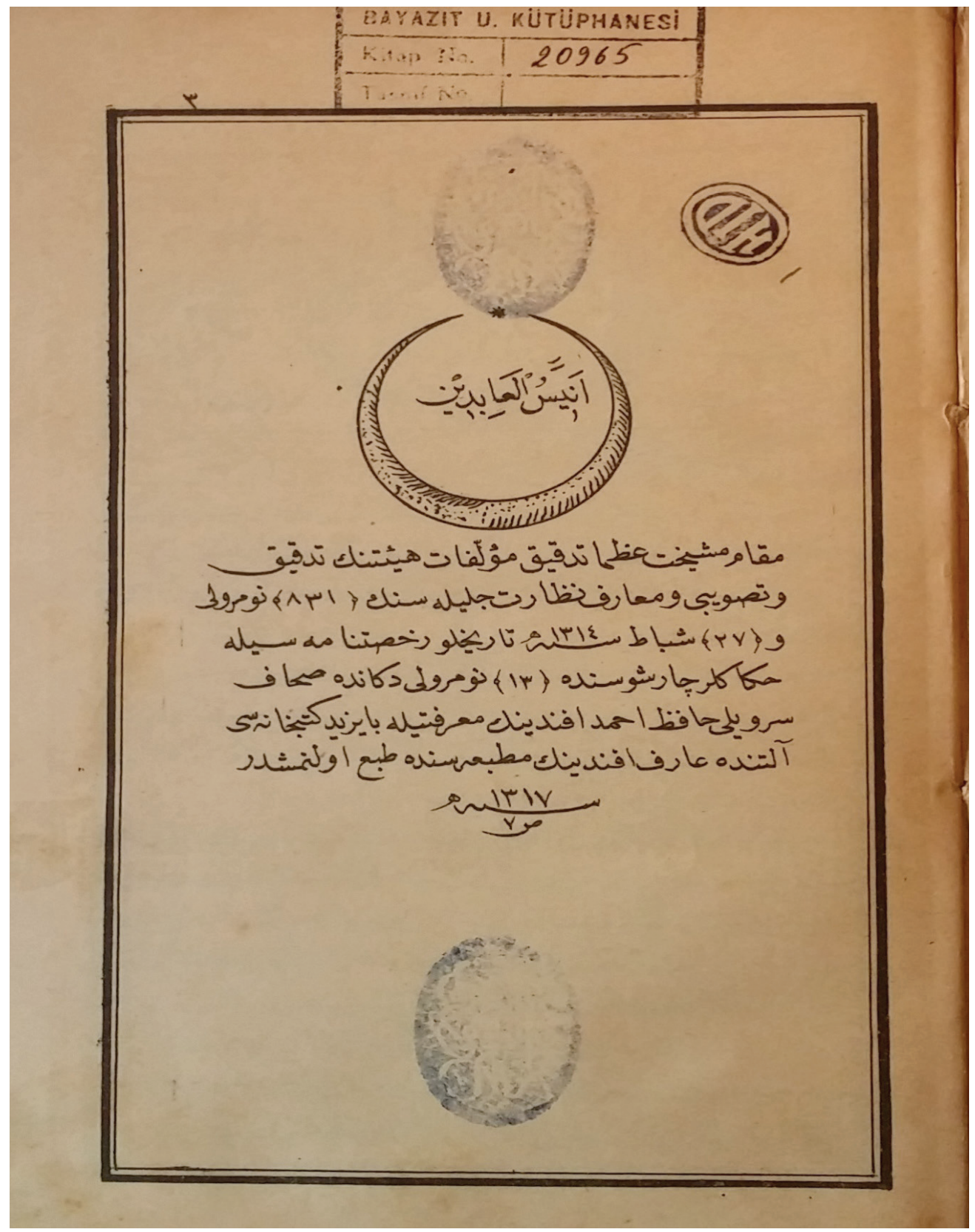




\section{Kaynaklar}

\section{Arşiv Kaynakları}

\subsection{Başbakanlık Osmanlı Arşivi}

Dâhiliye Nezareti Mektubi Kalemi (DH MKT)

İrade Taltifat (İ TAL)

İrade Dâhiliye (İ DH)

Maarif Nezareti Mektubi Kalemi (Bundan sonra MF MKT)

Şura-yı Devlet (ŞD)

Yıldız Esas Evrakı (Y EE)

Yıldız Parekende Evrakı, Başkitabet (Y PRK BŞK)

Yıldız Sadaret Hususi Maruzat Evrakı (YA HUS)

Yıldız Parekende Evrakı, Meşihat (Y PRK MŞ)

\subsection{Meşihat Arşivi}

Tedkîk-i Mesâhif ve Müellefât-1 Şer'iyye Dairesi Defterleri nr. 1784, 1785.

Fetvahane-i Âli Tezkire Defterleri nr. 379

Nezaret Amed Defterleri nr. 1509.

\section{Diğer Kaynaklar}

Akgündüz, Murat. “Osmanlı Padişahlarının Özel İmamları: İmâm-1 Sultânîler.” İstem, 2006, IV, sy. 7, s. 6574.

Alak, Musa. “Süleyman Sırrı.” DİA, EK-II, 544-5.

Albayrak, Sadık. Son Devir Osmanlı Uleması. I-V, İstanbul: İstanbul Büyükşehir Belediyesi, 1996.

Bursalı Mehmet Tahir. Osmanlı Müellifleri (haz. Ali Fikri Yavuz - İsmail Özen). İstanbul: Meral Yayınevi, I-III, ts.

Demirel, Fatmagül. “Osmanlı Devleti’nde Telif Hakları Sorunu.” Bilgi ve Bellek, Kış 2006, sy. 5, s. 93-104.

Dığıroğlu, Filiz. "II. Abdülhamid Dönemi Matbuat Politikaları: Mushaf Basımı ve Dini Neşriyat." II. Abdülhamid Han ve Dönemi (ed. Fahrettin Gün - Halil İbrahim Erbay), Ankara: TBMM Basımevi, 2017, s. 634-637.

------. “II. Abdülhamid Döneminde Dinî Yayıncılık: İslami Metinleri Kim Üretir? - I.” History Studies, Mart 2017, IX, sy.1, s. 85-110.

-------. “Osmanlı Matbuat Tarihinin Kaynağı Olarak Meşihat Arşivi.” II. Uluslararası Osmanlı Coğrafyası Arşiv Kongresi (20-24 Kasım 2017), (basılmamış tebliğ).

------. Dersaadet’te Bir Acem Kitapçı: Kitap-füruş Hacı Hüseyin Ağa. İstanbul: Turkuaz Yayınları, 2014.

Dilbaz, Mahmut. II. Abdülhamid Döneminde Mektep Sisteminde İslâm Anlayışı (doktora tezi, 2017). Ankara Üniversitesi Sosyal Bilimler Enstitüsü.

Fortna, Benjamin. Geç Osmanlı ve Erken Cumhuriyet Dönemlerinde Okumayı Öğrenmek (trc. Mehmet Beşikçi). İstanbul: Koç Üniversitesi, 2013.

Güldöşüren, Arzu, "Vildan Fâik Efendi”, DİA, XLIII, 108-9.

Hilafet Risâleleri (haz. İsmail Kara). I, İstanbul: Klasik Yayınları, 2002.

İhsanoğlu, Ekmeleddin. Misır'da Türkler ve Kültürel Mirasları. İstanbul: İslâm Tarih, Sanat ve Kültür Araştırma Merkezi, 2006. 
İpşirli, Mehmet. “Dersiam.” DİA, IX, 185-6.

İrtem, Süleyman Kani. Abdülhamid Devrinde Hafiyelik ve Sansür: Abdülhamid’e Verilen Jurnaller (haz. Osman Selim Kocahanoğlu). İstanbul: Temel Yayınları, 1999.

Kabacalı, Alpay. Başlangıçtan Günümüze Türkiye’de Basın Sansürü. İstanbul: Gazeteciler Cemiyeti Yayınları, 1990.

Kara, İsmail. Müslüman Kalarak Avrupalı Olmak-Çağdaş Türk Düşüncesinde Din Siyaset Tarih Medeniyet. İstanbul: Dergâh Yayınları, 2017.

--------. “İsmail Hakkı (Manastırlı).” Yaşamları ve Yapıtlarıyla Osmanlılar Ansiklopedisi, İstanbul 1999, I, 671-2.

--------. İlim Bilmez Tarih Hatırlamaz Şerh ve Haşiye Meselesine Dair Birkaç Not. İstanbul: Dergâh Yayınları, 2011.

Kasâid-i Tevfik. İstanbul: Mihran Matbaası 1304.

Koloğlu, Orhan. Osmanlı Dönemi Basınının İçeriği. İstanbul: İstanbul Üniversitesi İletişim Fakültesi 2010.

Köksal, Asım Cüneyd. "Bir İslâm Âlimi Olarak Lütfi Paşa." Osmanlı Araştırmaları, 2017, sy. 50, s. 29-72.

Köksal, M. Fatih. Mevlid-nâme. Ankara: Türkiye Diyanet Vakfı, 2011.

Mehmed Nahif el-Hâc. İlaveli Enîsüll-âbidîn. İstanbul: Matbaa-i Ahmed İhsan, 1327.

Meydan, Hasan. "Osmanlı Son Döneminden Ahlâk ve Terbiye’ye İki Farklı Yaklaşım: Abdullah Şevket ve Mehmet Hazık’ın Ahlâk ve Terbiye Anlayışları Üzerine Bir Karşılaştırma.” Tarih Okulu Dergisi 2017, sy. 29 , s. $1-22$.

Meziyyetü'l-İslâm. Dersaadet: Mahmut Bey Matbaası 1306.

Muhammed Nahif b. el-Hac Ahmed Kayseri. Enîsü’l-âbidîn. Dersaadet: Hacı Abbas Efendi Matbaası, 1323.

Özervarl, M. Sait. "Nebhani, Yusuf b. İsmail.” DİA, XXXII, 471-2.

Şeker, Şemsettin. Ders ile Sohbet Arasında Ondokuzuncu Asır İstanbulu’nda İlim, Kültür ve Sanat Meclisleri. İstanbul: Zeytinburnu Belediyesi Yayınları, 2013.

Uzun, Mustafa. "Mehmed Fevzi." DİA, XXII, 506-9.

Yalman, Ahmet Emin. Modern Türkiye’nin Gelişim Sürecinde Basın 1831-1913. İstanbul: Türkiye İş Bankası Kültür Yayınları, 2018.

Yaşaroğlu, Kamil. “Mahmud Esad Seydişehrî.” Yaşamları ve Yapıtlarıyla Osmanlılar Ansiklopedisi. İstanbul: Yapı Kredi Kültür Sanat Yayıncılık, 1999, II, 68-9.

Yıldız, Güllü. “II. Meşrutiyet Dönemi Siyer Müellifleri Arasında Geleneğin Sesi: Düzceli Yusuf Suad.” Divan Disiplinlerarası Çalışmalar Dergisi, 2010, XV, sy. 29, s. 63-93.

-. “İki Siyer Tek Müellif: Düzceli Yusuf Suad'ın Siyer Telifleri.” Otur Baştan Yaz Beni: Oto/Biyografiye Taze Bakışlar (haz. Abdulhamit Kırmız1). İstanbul: Küre Yayınları, 2013, s. 227-262.

Yılmaz, Ömer - Mine Oymak. "Edirne Müftüsü Mehmed Fevzî Efendi ve Vesîle-i Saâdet Adlı Eseri /Master Mehmet Fevzi-the mufti of Edirne and his work "Vesîle-i Saâdet" (the conducive to happiness)." Turkish Studies (Prof. Dr. Mehmet Akkuş Armağan1), 2016, XI, sy.17, s. 583-608.

Yörük, Ali Adem. Müderris ve Hukukçu Rizeli Hafız Kasım Efendi. İstanbul: Dergâh Yayınları, 2014.

Yurdakul, İlhami. Osmanl Devletinde Şer'i Temyiz Kurumları: Fetvahane-i Ali, Meclis-i Tedkikat-ı Şer'iyye ve Mahkeme-i Temyiz Şer'iyye Dairesi (yüksek lisans tezi 1996). Marmara Üniversitesi Sosyal Bilimler Enstitüsü.

Yücer, Hür Mahmut. “Bir İbn Arabî Müdafaası: Çerkeşîâade Mehmed Tevfîk Efendi ve Levâyihu’l-kudsiyye fî fedâili’ş - Şeyhi'l-Ekber adlı Eseri.” Tasavvuf (İbnü’l-Arabî Özel Sayıs1-1), 2008, IX, sy. 21, s. 331-351.

Mehmed Nahif el-Hâc, İlaveli Enîsü’l-âbidîn, İstanbul: Matbaa-i Ahmed İhsan, 1327, 142 s. 